\title{
AFIP-6 Breach Assessment Report
}

Dan Wachs

Adam Robinson

Pavel Medvedev

February 2011

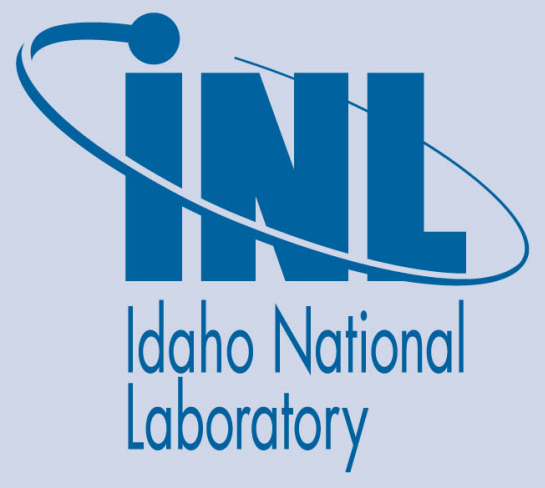

The INL is a U.S. Department of Energy National Laboratory operated by Battelle Energy Alliance 
INL/EXT-11-21110

\title{
AFIP-6 Breach Assessment Report
}

\author{
Dan Wachs \\ Adam Robinson \\ Pavel Medvedev
}

February 2011

\section{Idaho National Laboratory \\ Reduced Enrichment for Research and Test Reactors Program Nuclear Fuels and Materials Division \\ Idaho Falls, Idaho 83415 \\ htto://www.inl.qov}

Prepared for the

U.S. Department of Energy

Office of National Nuclear Security Administration

Under DOE Idaho Operations Office

Contract DE-AC07-05ID14517 


\section{DISCLAIMER}

This information was prepared as an account of work sponsored by an agency of the U.S. Government. Neither the U.S. Government nor any agency thereof, nor any of their employees, makes any warranty, expressed or implied, or assumes any legal liability or responsibility for the accuracy, completeness, or usefulness, of any information, apparatus, product, or process disclosed, or represents that its use would not infringe privately owned rights. References herein to any specific commercial product, process, or service by trade name, trade mark, manufacturer, or otherwise, does not necessarily constitute or imply its endorsement, recommendation, or favoring by the U.S. Government or any agency thereof. The views and opinions of authors expressed herein do not necessarily state or reflect those of the U.S. Government or any agency thereof. 



\section{EXECUTIVE SUMMARY}

Analysis of the AFIP-6 experiment is summarized in this report in order to determine the cause of gaseous fission product release observed during irradiation. During the irradiation, a series of small fission product releases were observed. In order to limit the potential for primary coolant contamination, the operating cycle was terminated and the AFIP-6 experiment was removed for examination. Both in-canal and post-irradiation examination revealed the presence of an unusually thick oxide layer and discrete surface blisters on the fuel plates. These blisters were the likely cause of fission product release.

Subsequent detailed thermal hydraulic analysis of the experiment indicated that the combination of the high operating power and test vehicle configuration led to high nominal operating temperatures for the fuel plates. This elevated temperature led to accelerated surface corrosion and eventually spallation of the fuel plate cladding. The thermal insulating nature of this corrosion layer led to significantly elevated fuel meat temperatures that induced blistering.

Analysis was performed to validate a corrosion rate model and criteria for onset of spallation type surface corrosion were determined. The corrosion rate model will be used to estimate the oxide thickness anticipated for experiments in the future. The margin to the spallation threshold will then be used to project the experiment performance. 


\section{CONTENTS}

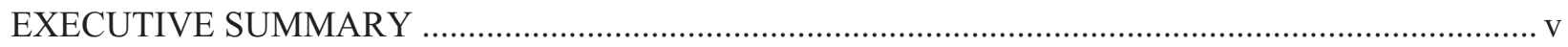

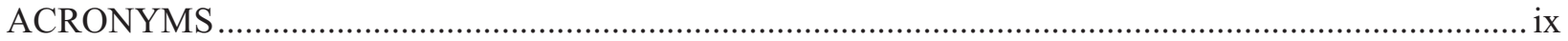

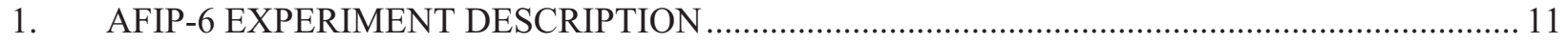

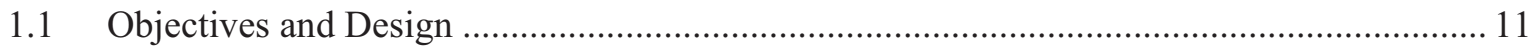

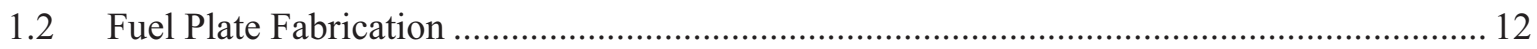

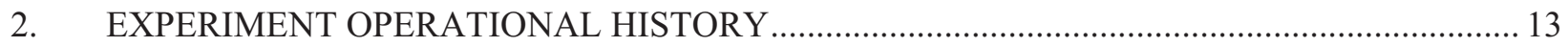

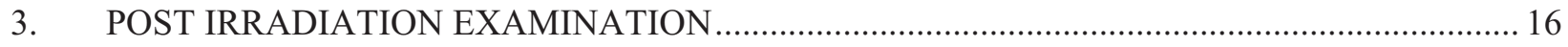

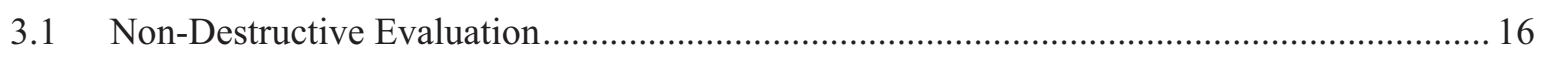

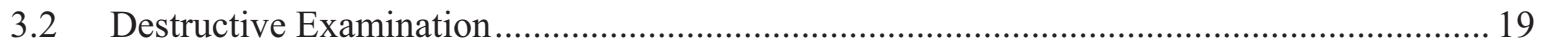

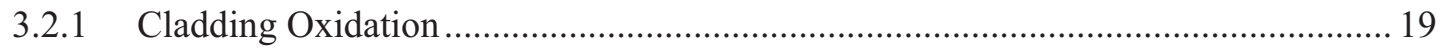

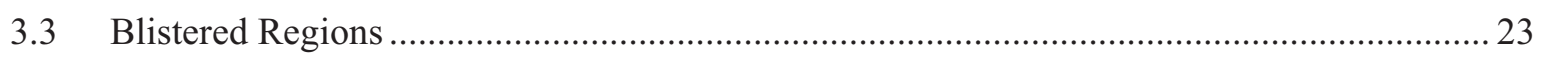

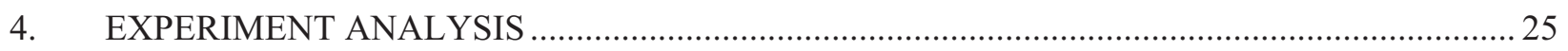

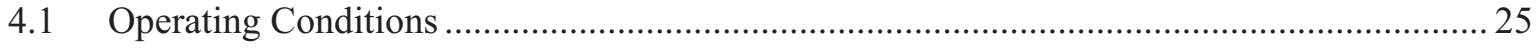

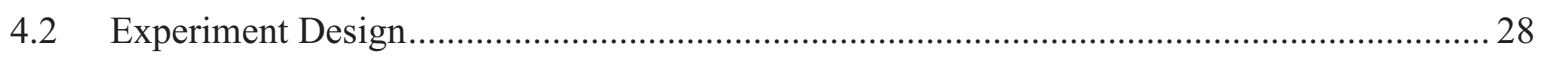

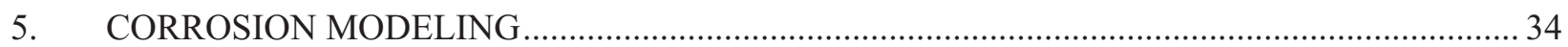

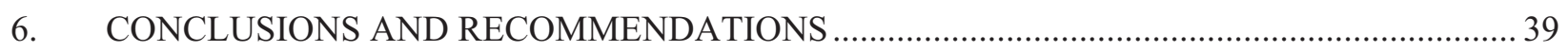

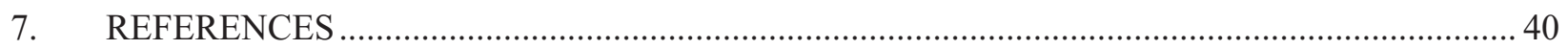

\section{FIGURES}

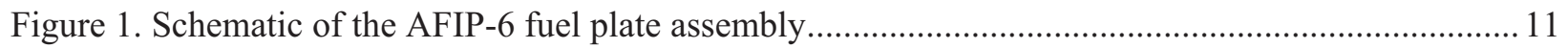

Figure 2. Schematic and photographs of the AFIP test vehicle. ........................................................ 12

Figure 3. ATR stack gas activity measured by the Real Time Monitor during ATR cycle 146B. ${ }^{7}$............ 13

Figure 4. ATR primary coolant activity during operation of the AFIP-6 experiment. ............................. 14

Figure 5. UT scans (thickness scan and transmission) and visual examination (middle) of the AFIP-6A (left) and -6B fuel plates (right). The clipped upper corner of the foil is clear in both UT images and is used to identify common orientations of the plate. ........................... 15

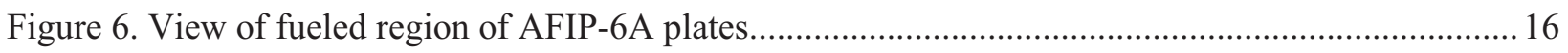

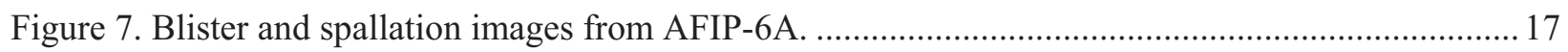

Figure 8. Location of oxide measurements (each location indicates 3 measurements)........................... 18

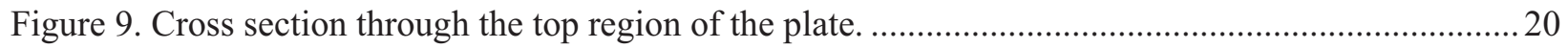

Figure 10. Oxidized and spalled surface of the cladding....................................................................... 21

Figure 11. High magnification image of degraded aluminum zone...........................................................22 
Figure 12. Image of cladding surface indicating spallation of the oxide layer. The U-Mo fuel is at the lower left.

Figure 13. Cross section through blister at lowest fueled region of the plate (left) and down plate length showing edge behavior (right).

Figure 14. Axial distribution of AFIP-6A fuel plate surface heat fluxes over the course of irradiation.

Figure 15. Center Flux Trap lobe power profile for ATR Cycle 146B....................................................2 27

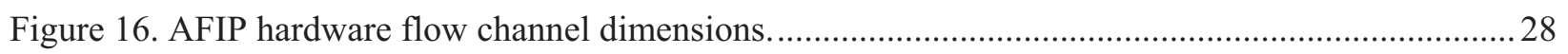

Figure 17. Convective heat transfer coefficients as a function of coolant velocity for several experiment hardware designs (RERTR, GTL, and AFIP) and the ATR driver element.

Figure 18. Coolant to Fuel Plate Surface Temperature Difference as a function of surface heat flux for the RERTR, GTL, AFIP and ATR driver element configurations. 30

Figure 19. Calculated fission density in AFIP-6A fuel plate at the end of irradiation.

Figure 20. Estimated AFIP-6 fuel plate operating temperatures as a function of axial position on the fuel plate. 32

Figure 21. Blister thresholds for common aluminum clad plate type fuel. 33

Figure 22. Specimen cross-section after spallation with subsurface attack. ${ }^{25}$..... .35

Figure 23. Irradiation time to the spallation onset for a range of the heat flux values. Given expected heat flux and oxide-water surface temperature, the chart can be used to estimate irradiation time to the onset of spallation. 36

Figure 24. Oxide thickness calculated using Equation (2) versus measured oxide thickness .36

\section{TABLES}

Table 1. Oxide thickness (measured by eddy current) results for the face (stamped side) and back of plate AFIP-6A as a function of axial position on the plate from top. 18

Table 2. AFIP-6A fuel plate power history as a function of axial position. ${ }^{12}$..... .25

Table 3. Oxide thickness, temperature drop across the oxide layer and indication whether spallation has occurred for the axial locations on the plate predicted for the 29th day of AFIP-6 irradiation. 38

Table 4. Temperature drop across the oxide layer and indication whether spallation has occurred for the axial locations on the plate predicted for the end of AFIP-6 irradiation. .38 


\section{ACRONYMS}

AFIP ATR Full-size Plate In Center Flux Trap Position

ATR Advanced Test Reactor

B\&W Babcock \& Wilcox

BR Breeder Reactor

CFT Center Flux Trap

EFPD effective full-power days

GTL Gas Test Loop

HFEF Hot Fuel Examination Facility

HFIR High-Flux Isotope Reactor (ORNL)

IAEA International Atomic Energy Agency (Austria)

INL Idaho National Laboratory

LEU low-enriched uranium (contains less than 20\% of U-235)

MCNP Monte Carlo Neutral Particle (transport code)

ORNL Oak Ridge National Laboratory

QA Quality Assurance

RERTR Reduced Enrichment Research and Test Reactors

SCK-CEN Studiecentrum voor Kernenergie - Centre d'Etude de l'énergie Nucléaire UT ultrasonic 


\section{AFIP-6 Breach Assessment Report \\ 1. AFIP-6 EXPERIMENT DESCRIPTION \\ 1.1 Objectives and Design}

The AFIP-6 test is a 'bounding case' experiment meant to envelope the key licensed operating conditions (power and burnup) for both the ATR and HFIR U-Mo monolithic based LEU fuel designs. ${ }^{1,2}$ The reference ATR LEU monolithic fuel design ${ }^{3}$ and peak operating conditions were used as the basis of the experiment configuration and operating conditions. As such, the fuel plates are standard ATR thickness $\left(0.050\right.$ " thick) and the 0.020 " thick $\mathrm{UAl}_{\mathrm{x}}-\mathrm{Al}$ fuel core is replaced by a 0.015 " fuel foil. The fuel foil consists of a 0.013 " U-10Mo foil covered by a nominally 0.001 " thick Zr layer on each side. The foil is clad in the typical Al-6061 alloy. A peak operating surface heat flux of $500 \mathrm{~W} / \mathrm{cm}^{2}$ was selected to bound the reported peak ATR operating surface heat flux of $480 \mathrm{~W} / \mathrm{cm}^{2}$ for the HEU fuel design.

The plates were irradiated using the same test vehicle used for the AFIP-1, -2, -3 and -4 experiments (shown in Figure 2). This apparatus allows for two plate assemblies of the geometry shown in Figure 1. In previous tests, the entire length of the plate was occupied by the fuel zone. However, the AFIP- 6 fuel plates used $40 \%$ enriched fuel (rather than the $20 \%$ used in the previous tests) in order to achieve the desired powers. This increase in enrichment forced the fuel zone to be shortened to 22.5 " so that an acceptable non-fueled backup of equivalent reactivity worth could be produced.
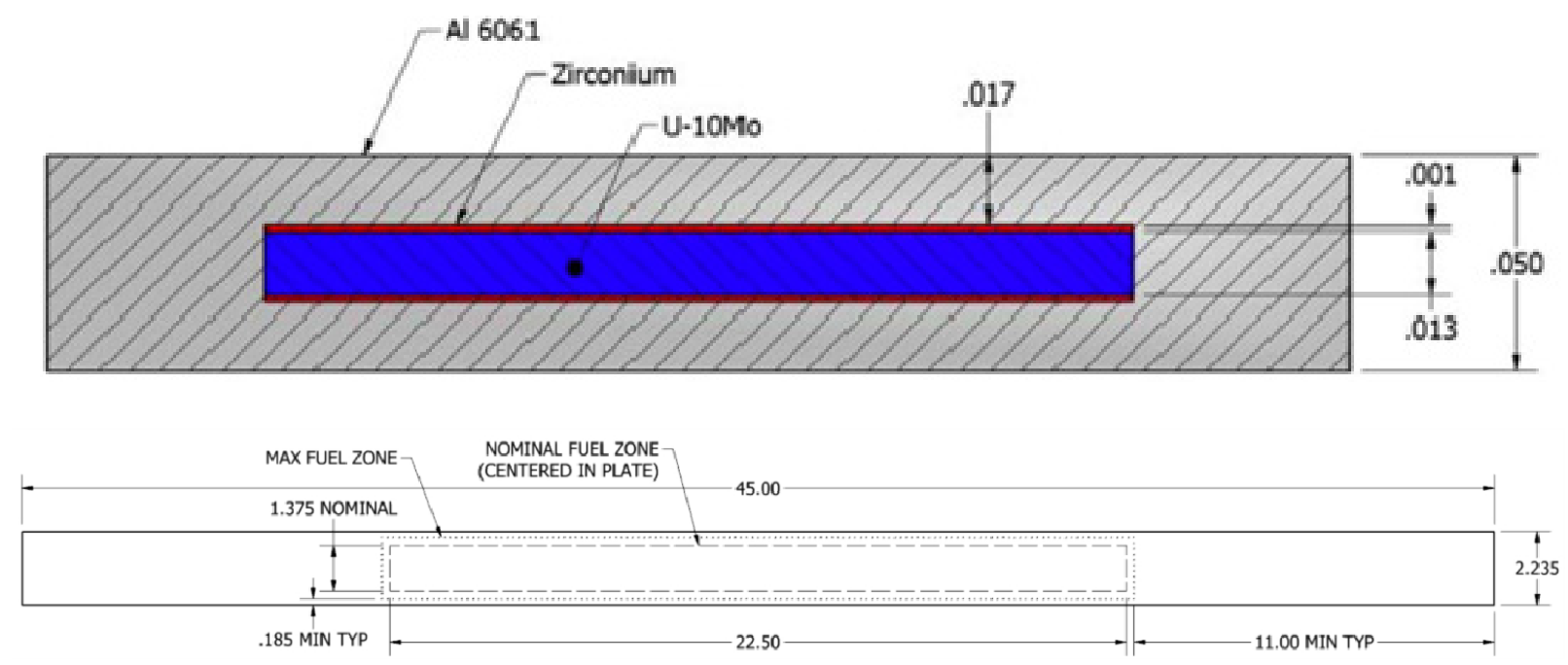

Figure 1. Schematic of the AFIP-6 fuel plate assembly. 

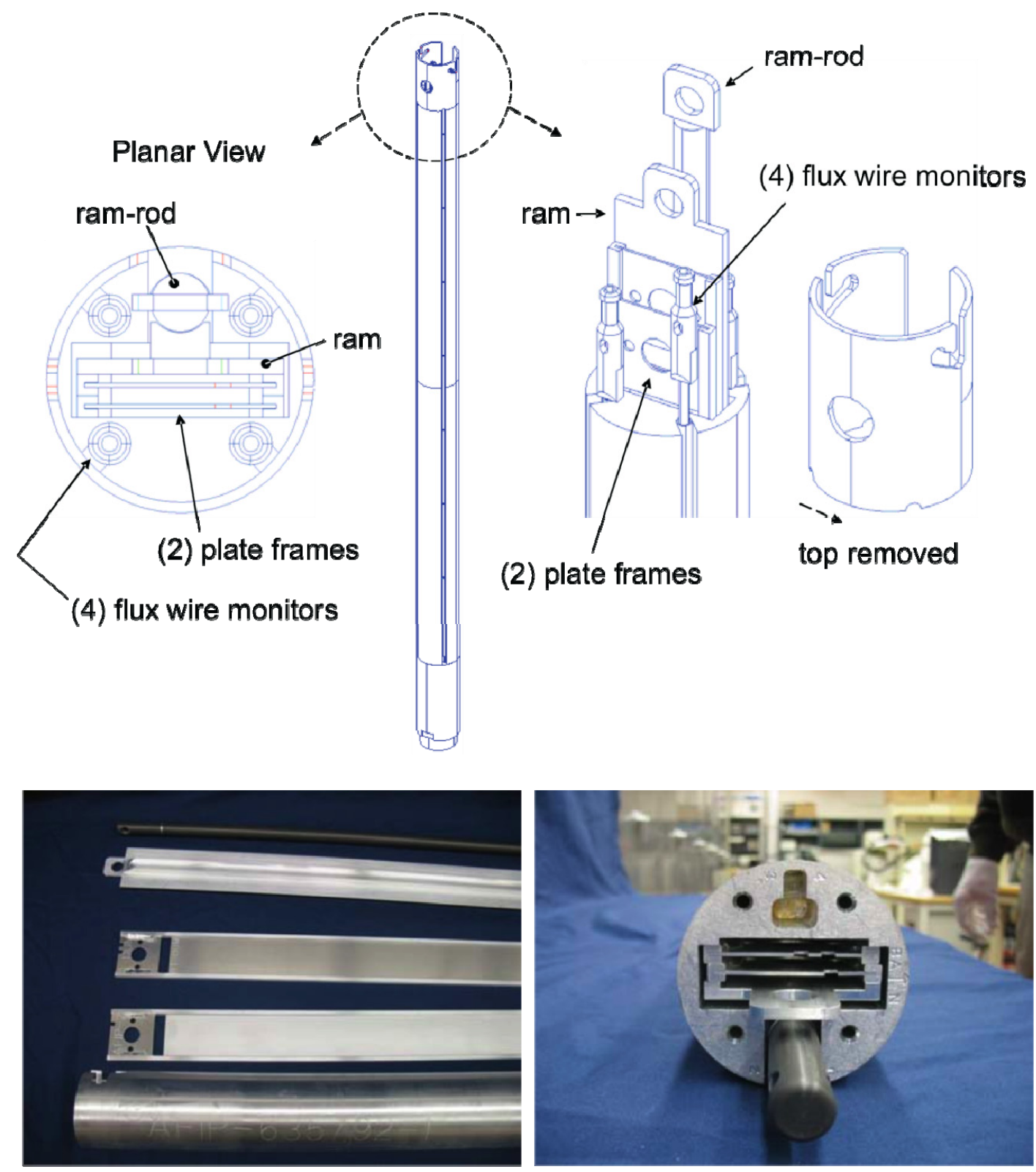

Figure 2. Schematic and photographs of the AFIP test vehicle.

\subsection{Fuel Plate Fabrication}

The AFIP-6 fuel plates were fabricating using processes previously demonstrated for both mini-plates and full-size plate experiments. ${ }^{4,5,6}$ The U-Mo coupons were induction cast in Oak Ridge Tennessee at the Y-12 National Security Complex. Fuel foils were fabricated at Idaho National Laboratory (INL) by first hot co-rolling to bond the zirconium diffusion barrier and then cold rolling to the final thickness. The Al-6061 cladding was applied by hot isostatic pressing at Babcock \& Wilcox (B\&W) in Lynchburg, Virginia. Finishing (including boehmite prefilm), final assembly, and QA were also performed at B\&W. 


\section{EXPERIMENT OPERATIONAL HISTORY}

The AFIP-6 experiment was inserted in the ATR Center Flux Trap position for cycle 146B which began in April 2010. The experiment had nearly completed the first of two planned irradiation cycles when minor fission product releases to the ATR primary coolant system were identified, ${ }^{7}$ prompting interruption of the test and thorough in-canal inspection.

ATR stack gas activity monitoring indicated that approximately five discrete releases occurred over the last week of operation as shown in Figure 3. It appears that individual blisters of different sizes may have ruptured and released fission gases into the coolant. As the gas pressure inside the blister was relieved, the stack gas activity trends back to normal levels after each event. It was also observed that the primary coolant system activity was largely unaffected by the events as shown in Figure 4 (an upward trend in activity is normal during a typical ATR operating cycle).

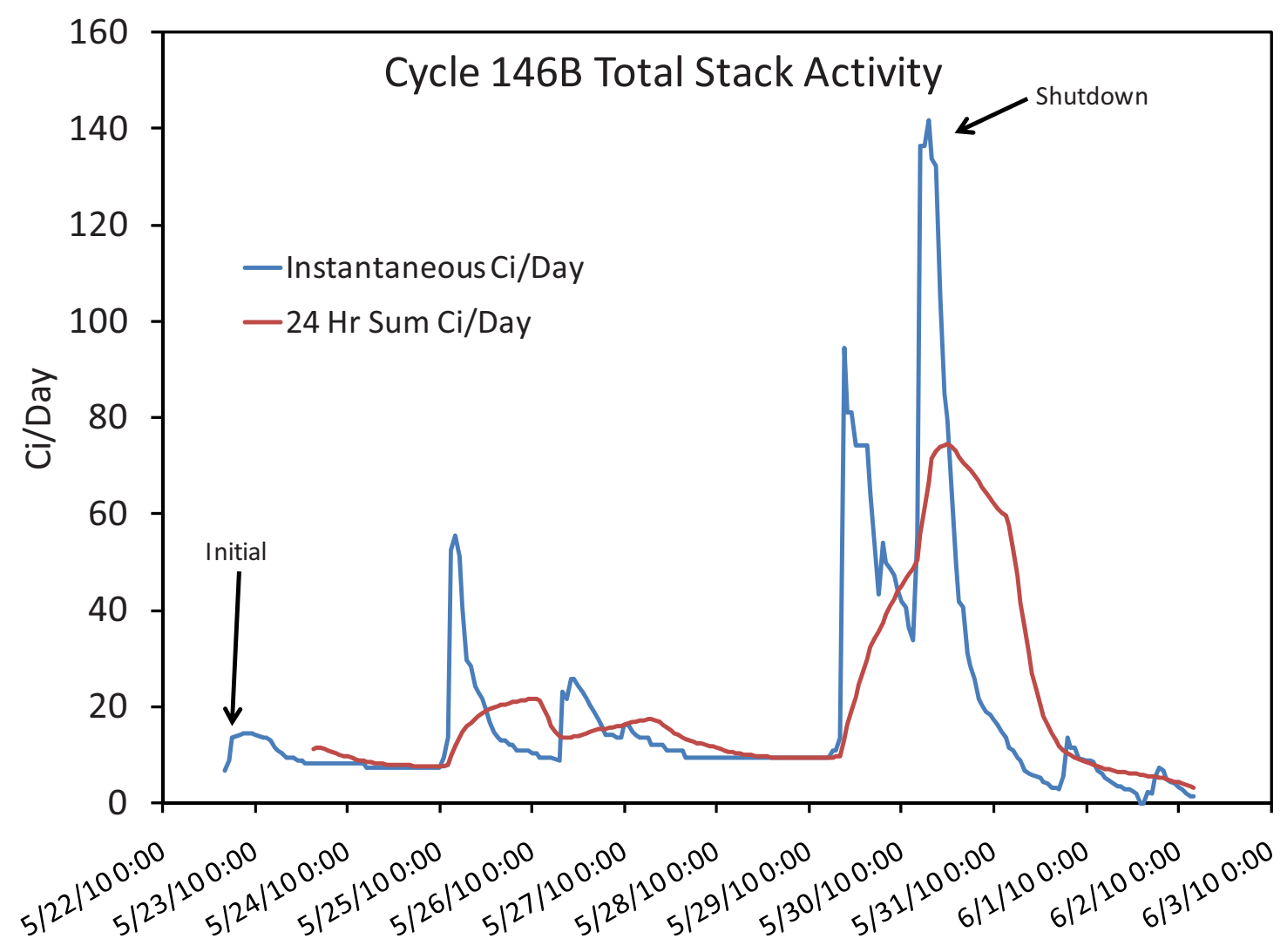

Figure 3. ATR stack gas activity measured by the Real Time Monitor during ATR cycle 146B. ${ }^{7}$ 


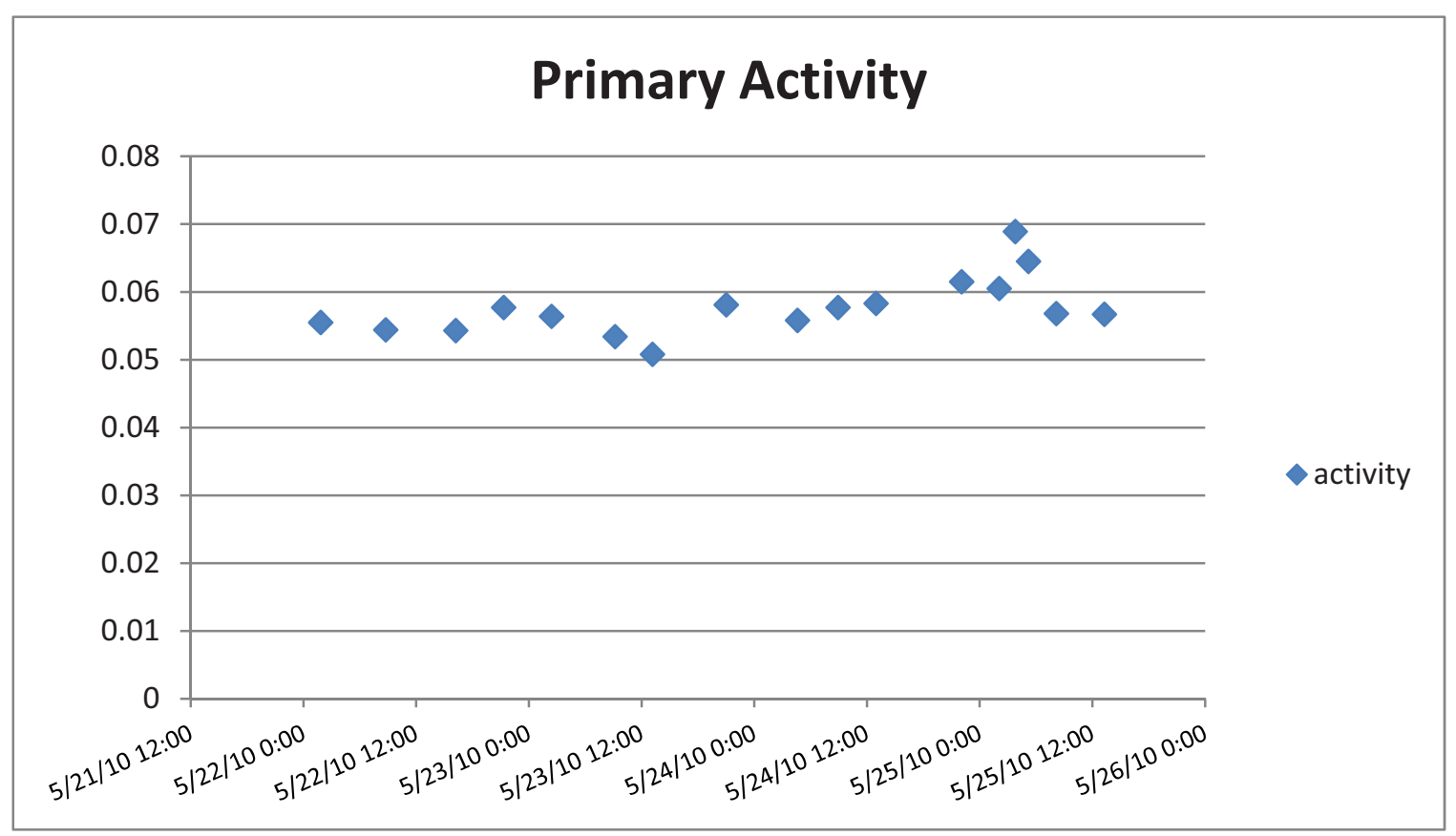

Figure 4. ATR primary coolant activity during operation of the AFIP-6 experiment.

In-canal soak testing of the AFIP-6 experiment indicated the presence of a cladding breach in at least one of the two plates included in the experiment. Subsequent, in-canal visual inspection of the AFIP-6A and $-6 \mathrm{~B}$ fuel plates showed dark, black discoloration over a large fraction of the fuel zone of both fuel plates that is indicative of abnormal oxide formation. Several small blisters were observed on the AFIP-6A fuel plate (which operated at higher power) and one blister was observed on the AFIP-6B fuel plate.

Visual examination of the fuel plate surface showed variable surface oxide conditions from the plate top to bottom. At the top of the fuel zone a region of typical oxide conditions was observed. This region was followed by a region that covered most of the fuel plate's fuel zone and consisted of a dark, rough textured layer that covered the hottest regions of the fuel plate.

In-canal ultrasonic (UT) examination was performed to further describe the surface morphology and internal features of both fuel plates. The UT scanner uses a 'transmission' based transducer to identify discontinuities inside the fuel, which are typically indicators of delamination or voids. This first examination confirmed the presence of small voids under the blistered regions of the fuel plate. The black spots shown on Figures $5 \mathrm{~b}$ and $5 \mathrm{~d}$ are the delaminated areas. The UT scanner can also operate in a 'reflection' mode that uses a time-of-flight method to measure the local plate thickness. The contour maps shown in Figures 5a and 5e show the presence of raised regions in these same areas as the larger delaminations. In combination, these signals clearly indicate the presence of blisters. The rectangular fuel region is evident in all three examination modes (visual, transmission, and reflection). 


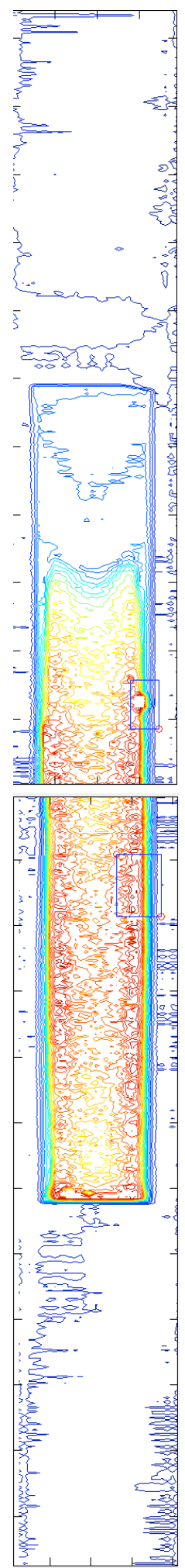

(a)
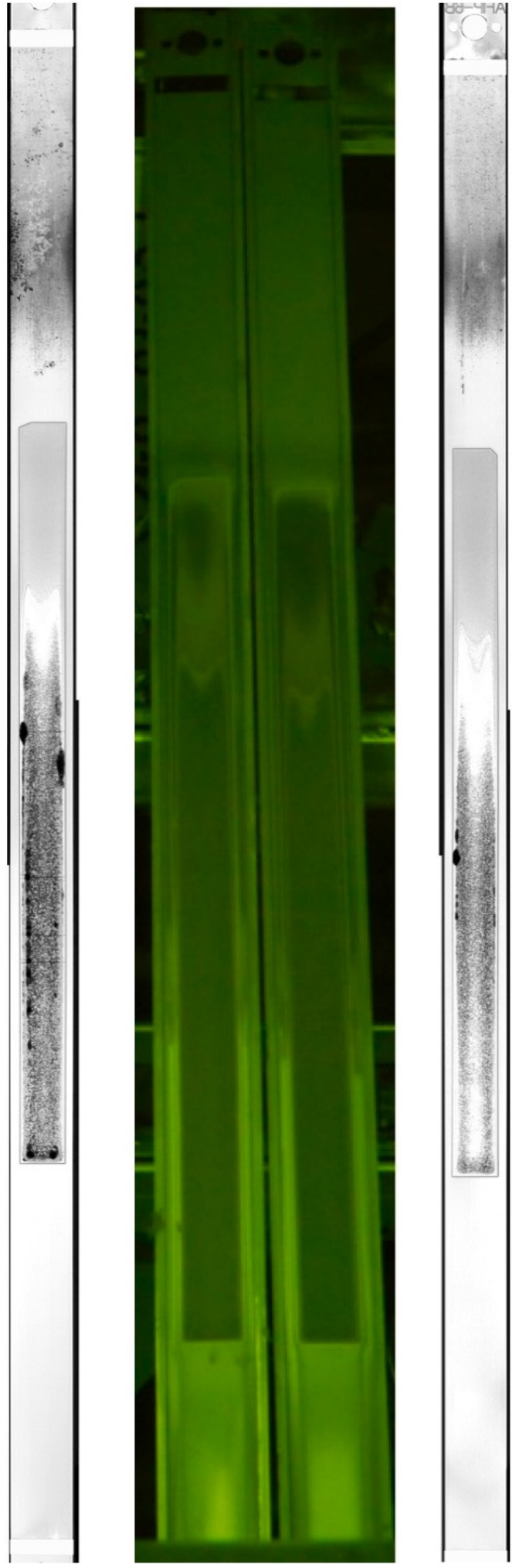

(b) (c) (d)
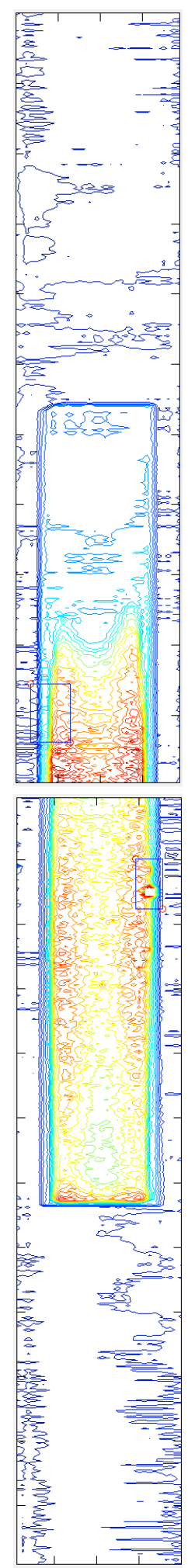

(e)

Figure 5. UT scans (thickness scan and transmission) and visual examination (middle) of the AFIP-6A (left) and -6B fuel plates (right). The clipped upper corner of the foil is clear in both UT images and is used to identify common orientations of the plate. 


\section{POST IRRADIATION EXAMINATION}

The experiment was shipped to the Hot Fuel Examination Facility (HFEF) for post irradiation examination after in-canal examinations confirmed that it had failed in reactor. In support of determining failure mechanisms and irradiation behavior, the AFIP-6A plate was selected for detailed analysis. The preliminary results obtained in that campaign are summarized herein.

\subsection{Non-Destructive Evaluation}

Visual examinations performed on both AFIP-6 plates in the hot cell confirm observations made during in-canal visual inspections performed at the ATR canal. Very dark oxidation was apparent starting approximately $45 \mathrm{~cm}$ (16 inches) from the top of the plate $(\sim 12 \mathrm{~cm}$ (5 inches) into the fueled region of the plate). A clear transition occurs from the typical boehmite oxide to the darker, rough surface as can be seen at the top of the plates in Figure 6. Peak power regions of the AFIP-6 plates showed additional abnormal surface behavior such as blistering and spallation of the surface oxide. Examples of these regions can be seen in Figure 7.
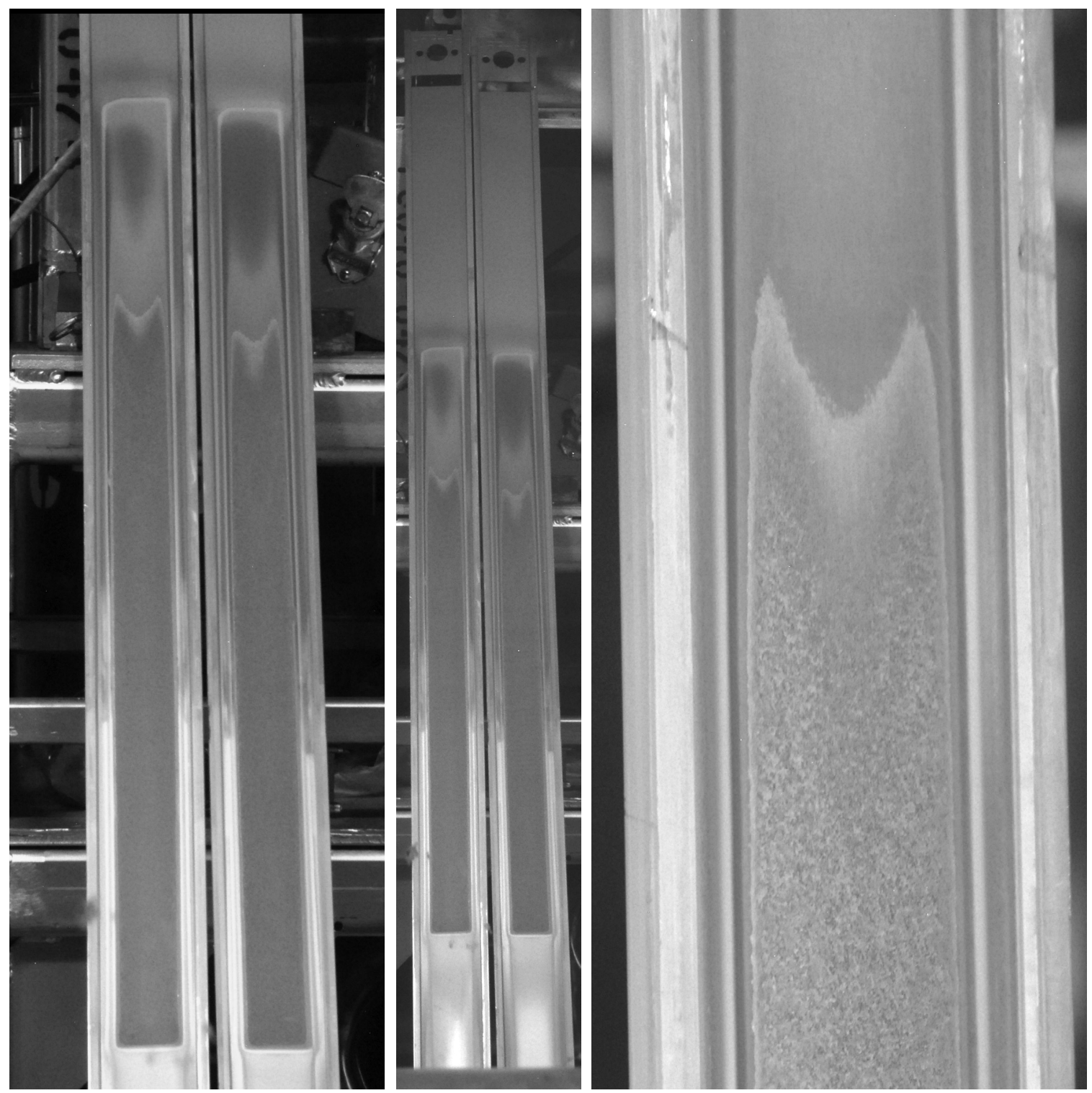

Figure 6. View of fueled region of AFIP-6A plates. 


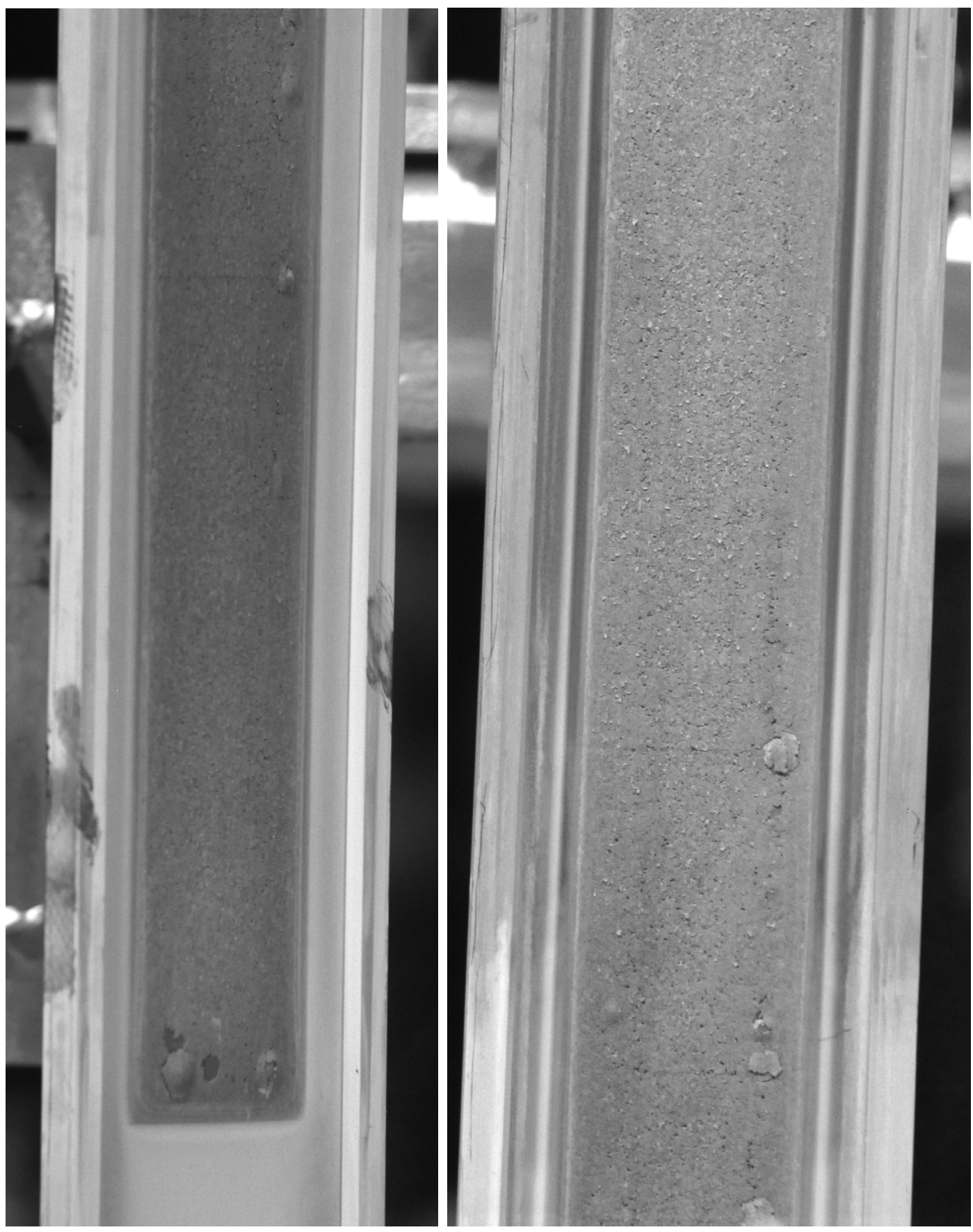

Figure 7. Blister and spallation images from AFIP-6A.

The surface oxide thickness distribution across the plate was measured using the eddy current method. The eddy current measurements taken on the AFIP-6 plates consisted of four equi-spaced, transverse measurements across the width of the plate at axial increments of $1.25 \mathrm{~cm}(0.5$ inches $)$ (Figure 8). Each point was measured three times to ensure statistical reliability. Both sides of the fuel plate (identified as 'face' and 'back') were measured. Due to the large number of data points collected, a summary of the values is provided in Table 1 . The summary provides the width averaged values at each $1.25 \mathrm{~cm}(0.5 \mathrm{inch})$ increment down the length of the plate. 


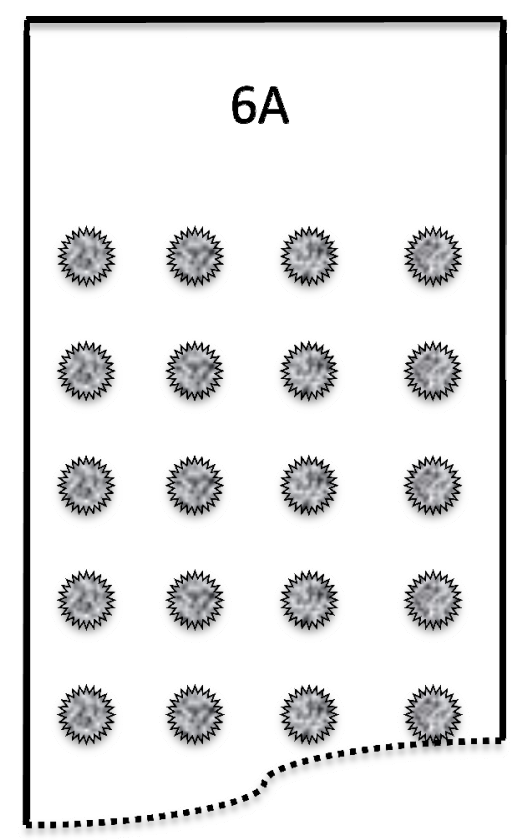

Figure 8. Location of oxide measurements (each location indicates 3 measurements).

Table 1. Oxide thickness (measured by eddy current) results for the face (stamped side) and back of plate AFIP-6A as a function of axial position on the plate from top.

\begin{tabular}{|c|c|c|c|c|c|c|c|c|}
\hline $\begin{array}{l}\text { Position } \\
\text { (cm) }\end{array}$ & $\begin{array}{l}\text { Face } \\
(\mu \mathrm{m})\end{array}$ & $\begin{array}{l}\text { Back } \\
(\mu \mathrm{m})\end{array}$ & $\begin{array}{l}\text { Position } \\
\text { (cm) }\end{array}$ & $\begin{array}{l}\text { Face } \\
(\mu \mathrm{m})\end{array}$ & $\begin{array}{l}\text { Back } \\
(\mu \mathrm{m})\end{array}$ & $\begin{array}{l}\text { Position } \\
\text { (cm) }\end{array}$ & $\begin{array}{l}\text { Face } \\
(\mu \mathrm{m})\end{array}$ & $\begin{array}{l}\text { Back } \\
(\mu \mathrm{m})\end{array}$ \\
\hline 1.4 & 1 & 0 & 43.0 & 41 & 41 & 72.8 & 207 & 197 \\
\hline 4.2 & 0 & 3 & 44.3 & 86 & 72 & 74.1 & 216 & 193 \\
\hline 6.8 & 0 & 3 & 45.6 & 96 & 97 & 75.4 & 262 & 188 \\
\hline 9.4 & 1 & 3 & 46.9 & 105 & 89 & 76.6 & 205 & 182 \\
\hline 12.0 & 1 & 4 & 48.2 & 128 & 115 & 77.9 & 213 & 199 \\
\hline 14.6 & 1 & 4 & 49.5 & 132 & 116 & 79.2 & 186 & 200 \\
\hline 17.1 & 1 & 4 & 50.8 & 135 & 117 & 80.5 & 177 & 191 \\
\hline 19.7 & 2 & 4 & 52.1 & 143 & 158 & 81.8 & 172 & 161 \\
\hline 22.3 & 2 & 4 & 53.4 & 158 & 142 & 83.1 & 158 & 167 \\
\hline 24.9 & 3 & 5 & 54.7 & 175 & 162 & 84.4 & 173 & 184 \\
\hline 27.5 & 4 & 5 & 56.0 & 177 & 178 & 85.7 & 234 & 261 \\
\hline 28.8 & 7 & 2 & 58.5 & 171 & 202 & 87.0 & 1 & 7 \\
\hline 30.1 & 11 & 15 & 59.8 & 183 & 182 & 88.3 & 1 & 8 \\
\hline 31.4 & 12 & 15 & 61.1 & 190 & 203 & 89.6 & 1 & 7 \\
\hline 32.7 & 14 & 17 & 62.4 & 195 & 216 & 90.9 & 0 & 7 \\
\hline 34.0 & 12 & 18 & 63.7 & 204 & 208 & 92.2 & 0 & 7 \\
\hline 35.3 & 11 & 19 & 65.0 & 213 & 228 & 93.5 & 0 & 10 \\
\hline 36.6 & 20 & 21 & 66.3 & 223 & 230 & 94.8 & 1 & 0 \\
\hline 37.9 & 22 & 20 & 67.6 & 227 & 209 & 96.1 & 0 & 1 \\
\hline 39.1 & 25 & 23 & 68.9 & 213 & 240 & 97.4 & 0 & 0 \\
\hline 40.4 & 30 & 28 & 70.2 & 227 & 212 & 98.7 & 0 & 0 \\
\hline \multirow[t]{2}{*}{41.7} & 27 & 26 & 71.5 & 240 & 187 & 100.0 & 0 & 0 \\
\hline & & & & & & 101.3 & 3 & 6 \\
\hline
\end{tabular}




\subsection{Destructive Examination}

\subsubsection{Cladding Oxidation}

Metallographic examination of the AFIP-6A plate was performed to better quantify the oxide formation on the cladding surface as well as to determine fuel behavior at locations suspected of failure. The plate was sectioned at nine locations associated with features of interest. Sections were taken both axially and transverse in order to examine artifacts seen in the previously described UT scans. A section was taken through the top of the plate where normal behavior is expected and through the bottom of the plate where the largest blisters were observed.

The cross section taken through the top region of the plate is shown in Figure 9. The surface of the cladding has behaved in a typical fashion with very little oxide growth. The fuel region also appears to have behaved well. Boehmite layer thickness values for RERTR mini- and full-size plates have been typically on the order of $20 \mu \mathrm{m}$ and are similar to that seen on the upper part of the fuel plate.

The second section taken from the blistered region of the fuel plate showed much different behavior. The oxide layer in the degraded region of the AFIP-6 plates consists of two distinct regions on top of the aluminum base metal and initial metallographic images (like Figure 10 and 11) indicate that values measured using the eddy current method were slightly lower than the actual thickness of the apparent degraded aluminum zone. The upper layer of the oxide film has characteristics similar to the typical boehmite oxide layer. Underneath the boehmite is a second layer of severely degraded aluminum. This underlying degraded zone appears to consist of oxide formation on grain boundaries of the aluminum and is consistent with layers observed to form under sever conditions during historic corrosion studies and a similar event that occurred at SCK-CEN in the Belgian BR2 reactor. ${ }^{8,9}$ Areas where spallation of the oxide has occurred are clearly evident in several metallographic images (Figure 12). Although localized removal of the oxide in the spalled region results in a temporary reduction in local fuel meat temperature, the layer is expected to regrow quickly in response to the degraded substrate, which no longer receives any protection from the boehmite and is directly exposed to the coolant. The morphology of the overall oxide film is consistent with the assumption that a cyclic process of oxide growth, substrate degradation, spallation, and further oxide formation occurred during irradiation. 


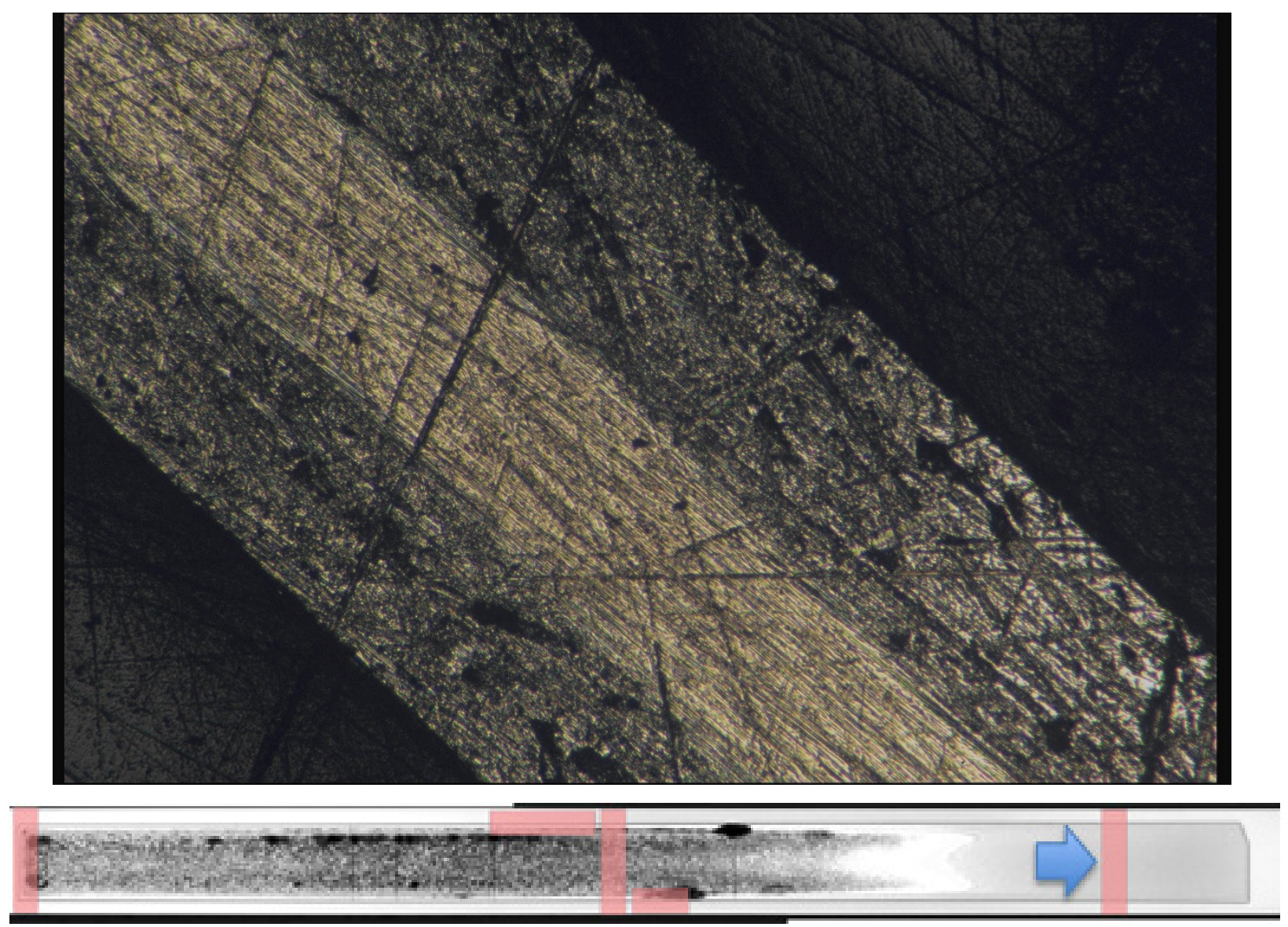

Figure 9. Cross section through the top region of the plate. 


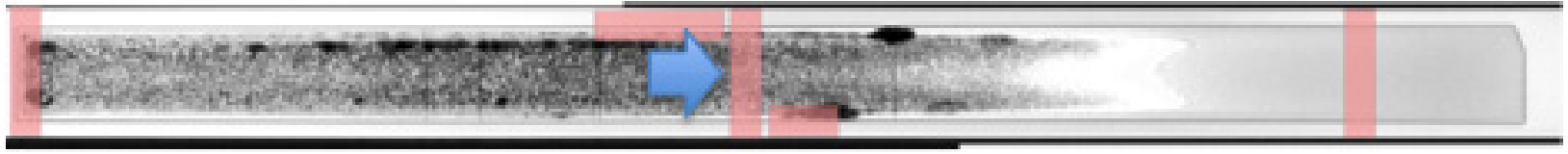

Figure 10. Oxidized and spalled surface of the cladding. 


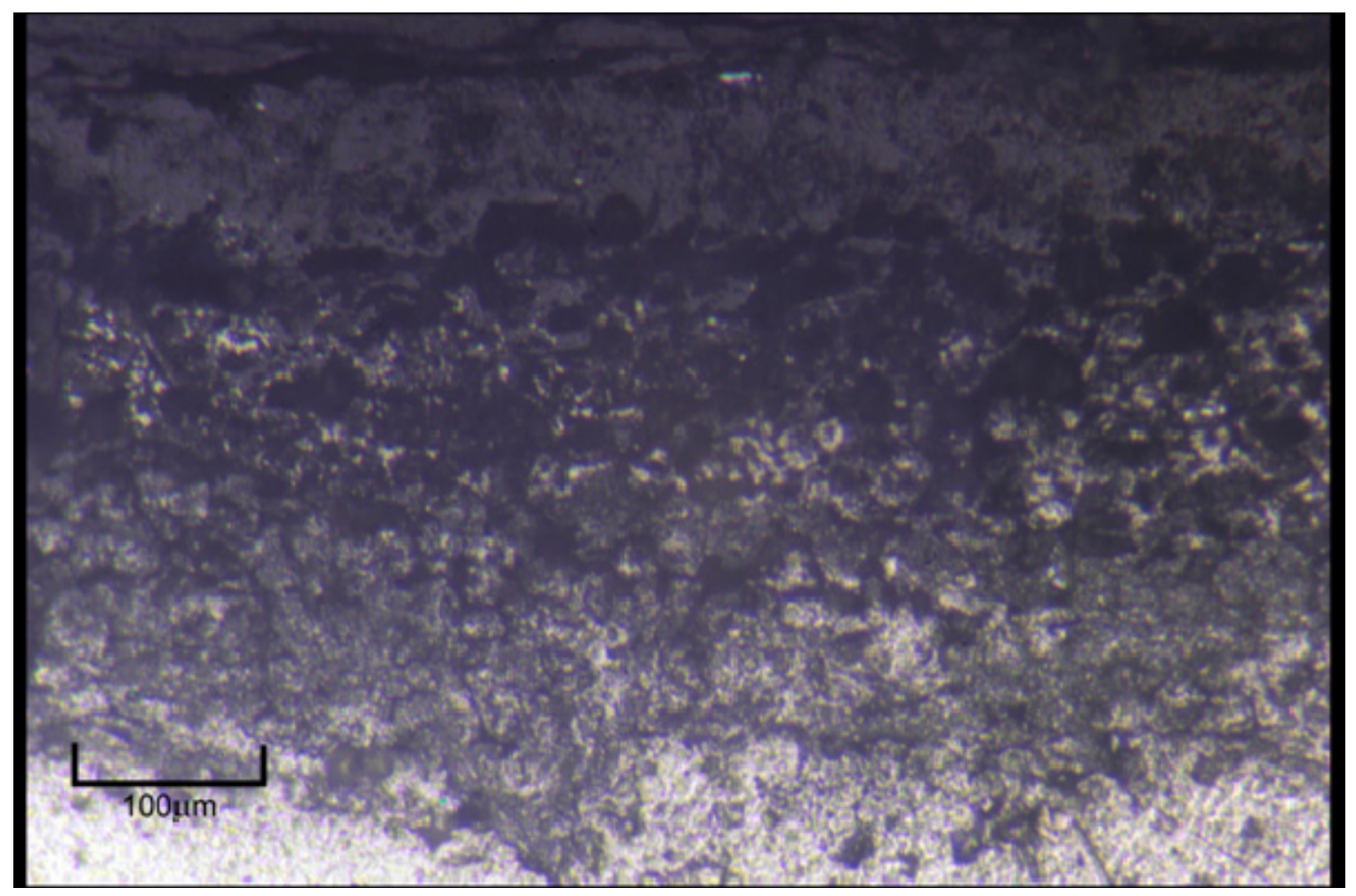

Figure 11. High magnification image of degraded aluminum zone.

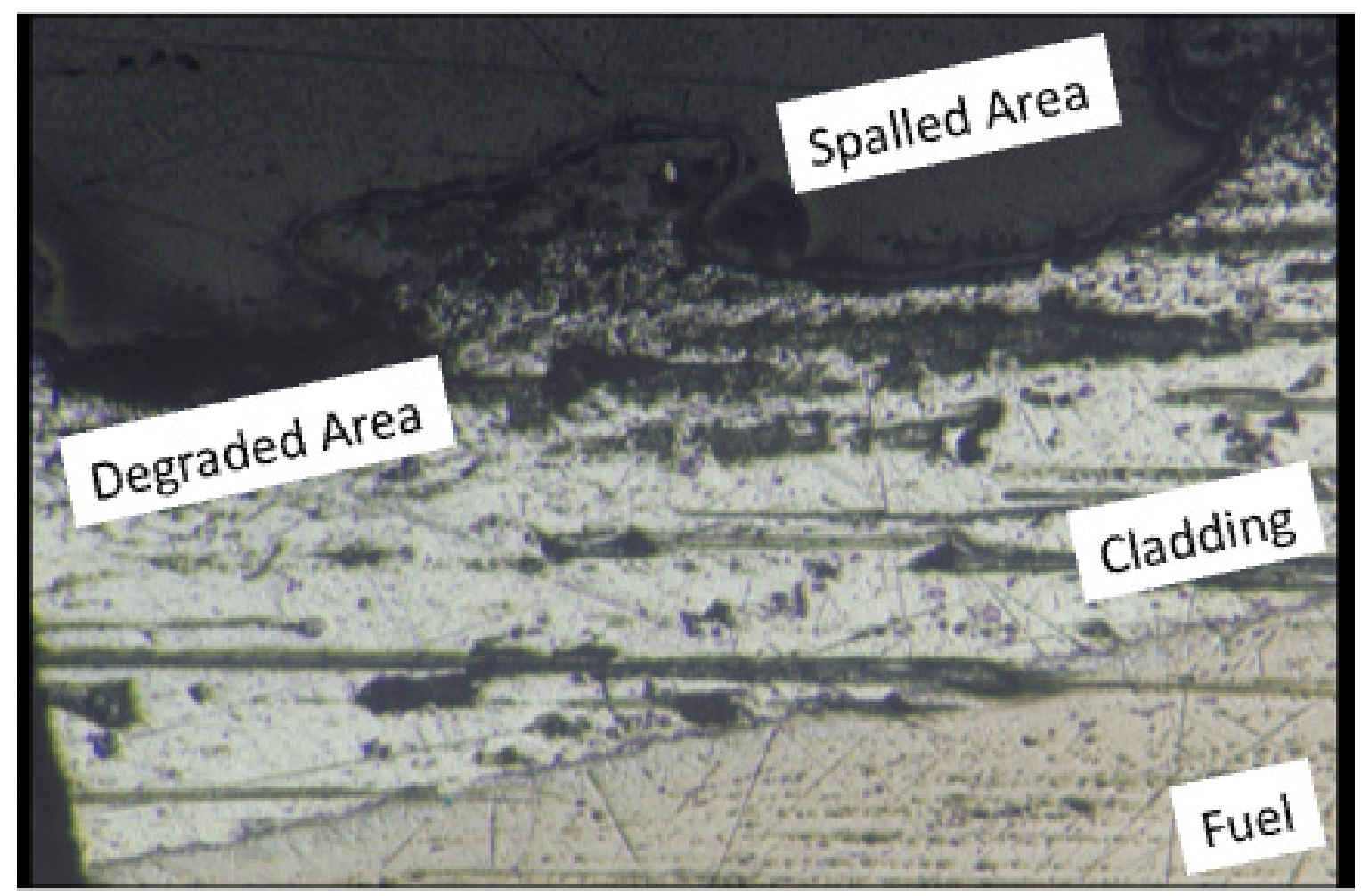

Figure 12. Image of cladding surface indicating spallation of the oxide layer. The U-Mo fuel is at the lower left. 


\subsection{Blistered Regions}

Ultrasonic scan images indicate the presence of defects in the hottest regions of the fuel plates. Samples were extracted from the fuel plate near several of these defects for metallographic inspection and a range of behaviors were observed.

A section of the plate taken near the bottom of the fueled region is shown in Figure 13. The section was taken through a large blister and, as expected, shows significant damage to the fuel. A relatively large void has formed near the centerline of the fuel foil and cracking is evident in the fuel around the void. Fuel meat cracking has also been observed in similar events experienced by dispersion fuel types and is attributed to the thermal cycling that occurs during shutdown. ${ }^{8}$ The severity of this phenomenon is greatly increased by the presence of a thick oxide film. The fuel plate 'blister' is clearly visible due to the change in fuel foil and cladding thickness. It is likely that cracks in the cladding over this blister resulted in release of fission gases to the primary coolant.

Sections were also extracted from the edge of the fuel plate where UT scans indicated damage but blisters were not yet evident. Figure 13 also includes a cross section taken in the axial direction near the edge of the fuel zone. This image shows that voids have begun to form a uniform distance from the fuel/cladding interface. It is anticipated that these defects will become 'sinks' for fission gases that will ultimately become large enough to cause blisters like those observed in hotter regions of the plate (i.e., that shown in Figure 13). 


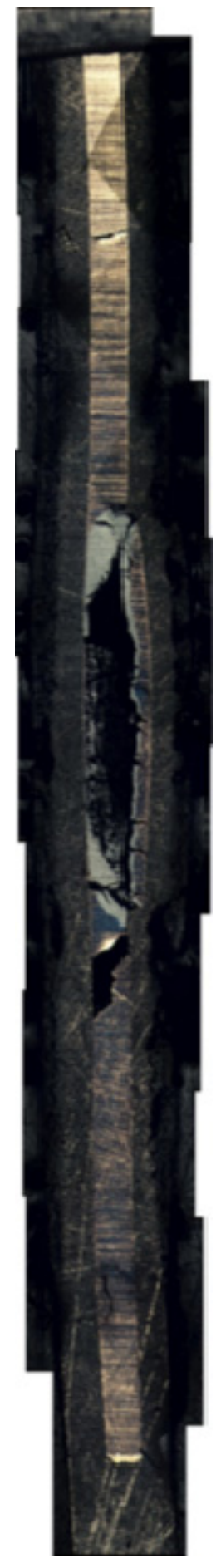

(a)

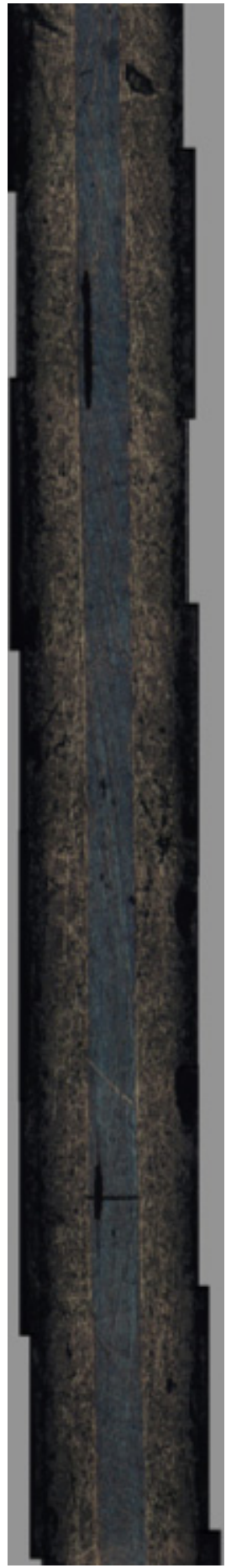

(b)

(a)

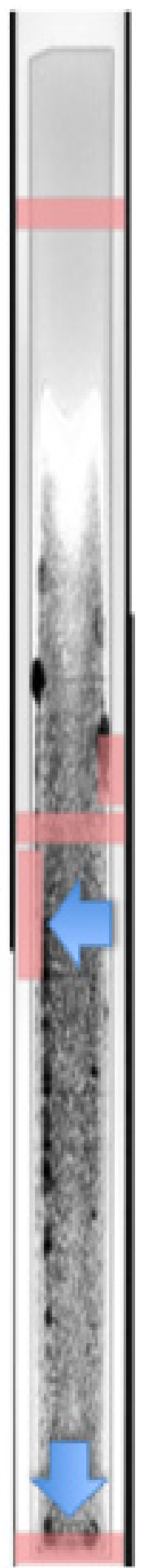

(b)

Figure 13. Cross section through blister at lowest fueled region of the plate (left) and down plate length showing edge behavior (right). 


\section{EXPERIMENT ANALYSIS}

The presence of a thick oxide layer would significantly increase the fuel meat operating temperature. It is well known that excessive fuel meat temperature in plate type fuel can lead to thermally induced blistering ${ }^{10,11}$ like that observed on the AFIP-6A fuel plate and that these blisters can rupture and release fission gases into the primary coolant system. It is also known that the rate of oxide formation on aluminum surfaces is strongly coupled to the fuel plate surface temperature. Analysis of the fuel plate operating conditions is summarized in the following sections.

\subsection{Operating Conditions}

MCNP calculations were performed to estimate the AFIP-6 fuel plate powers during the operating cycle. ${ }^{12}$ The calculations assume a center lobe power of $26 \mathrm{MW}$ and were reported at four points during the cycle $(0,18,28$ and 39.3 EFPDs) to account for fissile depletion. The nominal plate power values at $26 \mathrm{MW}$ can be scaled with the measured lobe power to determine the actual time-varying power. The calculated power distributions are summarized in Table 2 and the resulting surface heat flux is plotted in Figure 14. It is worth noting that because $40 \%$ enriched fuel was utilized in the experiment, the effect of fissile depletion is less pronounced than normal and the operating powers stay high throughout the irradiation. The nominal powers should be scaled up by $\sim 13 \%$ to account for an 'as-built' increase in foil thickness ${ }^{13}$ down the center of the foil (due to 'crowning'). Additional calculations performed to predict the two-dimensional power distribution in plates irradiated using the AFIP test vehicle ${ }^{14}$ showed that plate edge and corner power peaking (due to enhanced local themalization effects) can range from 10-30\%.

The Center Flux Trap lobe power as a function of time is shown in Figure 15. Several salient operational features are clear from this plot. First, the CFT power spikes appreciably at the beginning of the ATR operating cycle for a short period of time as the reactor overcomes xenon poisoning after startup. Near the end of the cycle, the CFT power begins to climb due to movement of outer control drum cylinders. Small spikes in the lobe power routinely occur due to movement of control shims and the outer control drum cylinders.

Table 2. AFIP-6A fuel plate power history as a function of axial position. ${ }^{12}$

\begin{tabular}{cccccc}
\hline & \multirow{4}{*}{$\begin{array}{c}\text { MCNP Cell } \\
\text { Centroid } \\
\text { Elevation } \\
\text { (inches) }\end{array}$} & 0 EFPD & 18 EFPD & $28 \mathrm{EFPD}$ & $39.3 \mathrm{EFPD}$ \\
\cline { 3 - 6 } Cell & 11.0 & $2.96 \mathrm{E}+04$ & $2.76 \mathrm{E}+04$ & $2.95 \mathrm{E}+04$ & $2.82 \mathrm{E}+04$ \\
\hline A-1 & 10.5 & $2.72 \mathrm{E}+04$ & $2.51 \mathrm{E}+04$ & $2.72 \mathrm{E}+04$ & $2.62 \mathrm{E}+04$ \\
A-2 & 10.0 & $2.77 \mathrm{E}+04$ & $2.56 \mathrm{E}+04$ & $2.72 \mathrm{E}+04$ & $2.61 \mathrm{E}+04$ \\
A-3 & 9.5 & $2.75 \mathrm{E}+04$ & $2.54 \mathrm{E}+04$ & $2.72 \mathrm{E}+04$ & $2.63 \mathrm{E}+04$ \\
A-4 & 9.0 & $2.78 \mathrm{E}+04$ & $2.56 \mathrm{E}+04$ & $2.77 \mathrm{E}+04$ & $2.66 \mathrm{E}+04$ \\
A-5 & 8.5 & $2.84 \mathrm{E}+04$ & $2.58 \mathrm{E}+04$ & $2.78 \mathrm{E}+04$ & $2.68 \mathrm{E}+04$ \\
A-6 & 8.0 & $2.86 \mathrm{E}+04$ & $2.63 \mathrm{E}+04$ & $2.82 \mathrm{E}+04$ & $2.72 \mathrm{E}+04$ \\
A-7 & 7.5 & $2.88 \mathrm{E}+04$ & $2.64 \mathrm{E}+04$ & $2.81 \mathrm{E}+04$ & $2.70 \mathrm{E}+04$ \\
A-8 & 7.0 & $2.93 \mathrm{E}+04$ & $2.63 \mathrm{E}+04$ & $2.85 \mathrm{E}+04$ & $2.74 \mathrm{E}+04$ \\
A-9 & 6.5 & $2.94 \mathrm{E}+04$ & $2.67 \mathrm{E}+04$ & $2.88 \mathrm{E}+04$ & $2.77 \mathrm{E}+04$ \\
A-10 & 6.0 & $2.98 \mathrm{E}+04$ & $2.72 \mathrm{E}+04$ & $2.87 \mathrm{E}+04$ & $2.76 \mathrm{E}+04$ \\
A-11 & 5.5 & $3.01 \mathrm{E}+04$ & $2.74 \mathrm{E}+04$ & $2.92 \mathrm{E}+04$ & $2.81 \mathrm{E}+04$ \\
A-12 & 5.0 & $3.03 \mathrm{E}+04$ & $2.75 \mathrm{E}+04$ & $2.94 \mathrm{E}+04$ & $2.82 \mathrm{E}+04$ \\
A-13 & 4.5 & $3.02 \mathrm{E}+04$ & $2.75 \mathrm{E}+04$ & $2.92 \mathrm{E}+04$ & $2.80 \mathrm{E}+04$ \\
A-14 & & & & &
\end{tabular}


Table 2. (continued).

\begin{tabular}{|c|c|c|c|c|c|}
\hline \multirow[b]{2}{*}{ Cell } & \multirow{2}{*}{$\begin{array}{l}\text { MCNP Cell } \\
\text { Centroid } \\
\text { Elevation } \\
\text { (inches) }\end{array}$} & \multicolumn{4}{|c|}{$\begin{array}{c}\text { Fission Power Density } \\
(\mathrm{W} / \mathrm{cc})\end{array}$} \\
\hline & & 0 EFPD & 18 EFPD & 28 EFPD & 39.3 EFPD \\
\hline A-15 & 4.0 & $3.06 \mathrm{E}+04$ & $2.76 \mathrm{E}+04$ & $2.93 \mathrm{E}+04$ & $2.80 \mathrm{E}+04$ \\
\hline A-16 & 3.5 & $3.06 \mathrm{E}+04$ & $2.80 \mathrm{E}+04$ & $2.94 \mathrm{E}+04$ & $2.83 \mathrm{E}+04$ \\
\hline A-17 & 3.0 & $3.12 \mathrm{E}+04$ & $2.77 \mathrm{E}+04$ & $2.97 \mathrm{E}+04$ & $2.85 \mathrm{E}+04$ \\
\hline A-18 & 2.5 & $3.13 \mathrm{E}+04$ & $2.85 \mathrm{E}+04$ & $2.99 \mathrm{E}+04$ & $2.87 \mathrm{E}+04$ \\
\hline A-19 & 2.0 & $3.12 \mathrm{E}+04$ & $2.83 \mathrm{E}+04$ & $2.98 \mathrm{E}+04$ & $2.86 \mathrm{E}+04$ \\
\hline A-20 & 1.5 & $3.14 \mathrm{E}+04$ & $2.82 \mathrm{E}+04$ & $2.98 \mathrm{E}+04$ & $2.86 \mathrm{E}+04$ \\
\hline A-21 & 1.0 & $3.15 \mathrm{E}+04$ & $2.85 \mathrm{E}+04$ & $2.99 \mathrm{E}+04$ & $2.87 \mathrm{E}+04$ \\
\hline A-22 & 0.5 & $3.15 \mathrm{E}+04$ & $2.86 \mathrm{E}+04$ & $2.99 \mathrm{E}+04$ & $2.87 \mathrm{E}+04$ \\
\hline A-23 & 0.0 & $3.13 \mathrm{E}+04$ & $2.82 \mathrm{E}+04$ & $3.01 \mathrm{E}+04$ & $2.88 \mathrm{E}+04$ \\
\hline A-24 & -0.5 & $3.18 \mathrm{E}+04$ & $2.88 \mathrm{E}+04$ & $2.99 \mathrm{E}+04$ & $2.87 \mathrm{E}+04$ \\
\hline A-25 & -1.0 & $3.13 \mathrm{E}+04$ & $2.84 \mathrm{E}+04$ & $2.99 \mathrm{E}+04$ & $2.86 \mathrm{E}+04$ \\
\hline A-26 & -1.5 & $3.17 \mathrm{E}+04$ & $2.84 \mathrm{E}+04$ & $3.02 \mathrm{E}+04$ & $2.89 \mathrm{E}+04$ \\
\hline A-27 & -2.0 & $3.13 \mathrm{E}+04$ & $2.83 \mathrm{E}+04$ & $2.97 \mathrm{E}+04$ & $2.85 \mathrm{E}+04$ \\
\hline A-28 & -2.5 & $3.16 \mathrm{E}+04$ & $2.86 \mathrm{E}+04$ & $2.98 \mathrm{E}+04$ & $2.85 \mathrm{E}+04$ \\
\hline A-29 & -3.0 & $3.12 \mathrm{E}+04$ & $2.80 \mathrm{E}+04$ & $2.97 \mathrm{E}+04$ & $2.85 \mathrm{E}+04$ \\
\hline A-30 & -3.5 & $3.14 \mathrm{E}+04$ & $2.84 \mathrm{E}+04$ & $2.99 \mathrm{E}+04$ & $2.87 \mathrm{E}+04$ \\
\hline A-31 & -4.0 & $3.12 \mathrm{E}+04$ & $2.80 \mathrm{E}+04$ & $2.97 \mathrm{E}+04$ & $2.86 \mathrm{E}+04$ \\
\hline A-32 & -4.5 & $3.10 \mathrm{E}+04$ & $2.79 \mathrm{E}+04$ & $2.97 \mathrm{E}+04$ & $2.84 \mathrm{E}+04$ \\
\hline A-33 & -5.0 & $3.09 \mathrm{E}+04$ & $2.80 \mathrm{E}+04$ & $2.96 \mathrm{E}+04$ & $2.85 \mathrm{E}+04$ \\
\hline A-34 & -5.5 & $3.07 \mathrm{E}+04$ & $2.80 \mathrm{E}+04$ & $2.96 \mathrm{E}+04$ & $2.85 \mathrm{E}+04$ \\
\hline A-35 & -6.0 & $3.03 \mathrm{E}+04$ & $2.77 \mathrm{E}+04$ & $2.96 \mathrm{E}+04$ & $2.84 \mathrm{E}+04$ \\
\hline A-36 & -6.5 & $2.99 \mathrm{E}+04$ & $2.72 \mathrm{E}+04$ & $2.92 \mathrm{E}+04$ & $2.81 \mathrm{E}+04$ \\
\hline A-37 & -7.0 & $3.03 \mathrm{E}+04$ & $2.70 \mathrm{E}+04$ & $2.90 \mathrm{E}+04$ & $2.78 \mathrm{E}+04$ \\
\hline A-38 & -7.5 & $3.01 \mathrm{E}+04$ & $2.72 \mathrm{E}+04$ & $2.86 \mathrm{E}+04$ & $2.76 \mathrm{E}+04$ \\
\hline A-39 & -8.0 & $2.95 \mathrm{E}+04$ & $2.65 \mathrm{E}+04$ & $2.87 \mathrm{E}+04$ & $2.77 \mathrm{E}+04$ \\
\hline A- 40 & -8.5 & $2.96 \mathrm{E}+04$ & $2.67 \mathrm{E}+04$ & $2.84 \mathrm{E}+04$ & $2.74 \mathrm{E}+04$ \\
\hline A-41 & -9.0 & $2.90 \mathrm{E}+04$ & $2.64 \mathrm{E}+04$ & $2.80 \mathrm{E}+04$ & $2.69 \mathrm{E}+04$ \\
\hline A-42 & -9.5 & $2.90 \mathrm{E}+04$ & $2.60 \mathrm{E}+04$ & $2.82 \mathrm{E}+04$ & $2.71 \mathrm{E}+04$ \\
\hline A-43 & -10.0 & $2.86 \mathrm{E}+04$ & $2.60 \mathrm{E}+04$ & $2.79 \mathrm{E}+04$ & $2.69 \mathrm{E}+04$ \\
\hline A-44 & -10.5 & $2.87 \mathrm{E}+04$ & $2.60 \mathrm{E}+04$ & $2.80 \mathrm{E}+04$ & $2.70 \mathrm{E}+04$ \\
\hline A- -45 & -11.0 & $3.13 \mathrm{E}+04$ & $2.86 \mathrm{E}+04$ & $3.01 \mathrm{E}+04$ & $2.87 \mathrm{E}+04$ \\
\hline
\end{tabular}




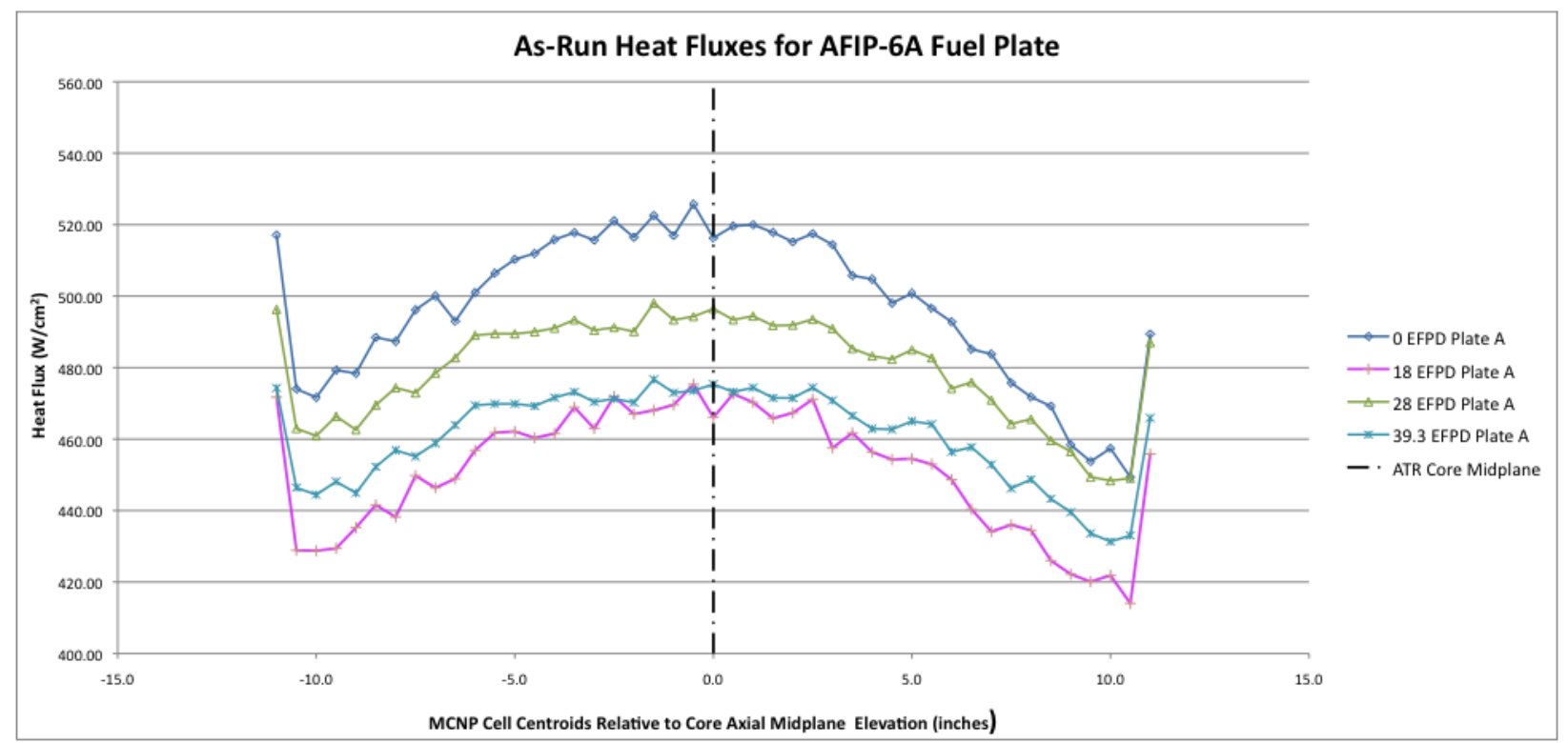

Figure 14. Axial distribution of AFIP-6A fuel plate surface heat fluxes over the course of irradiation.

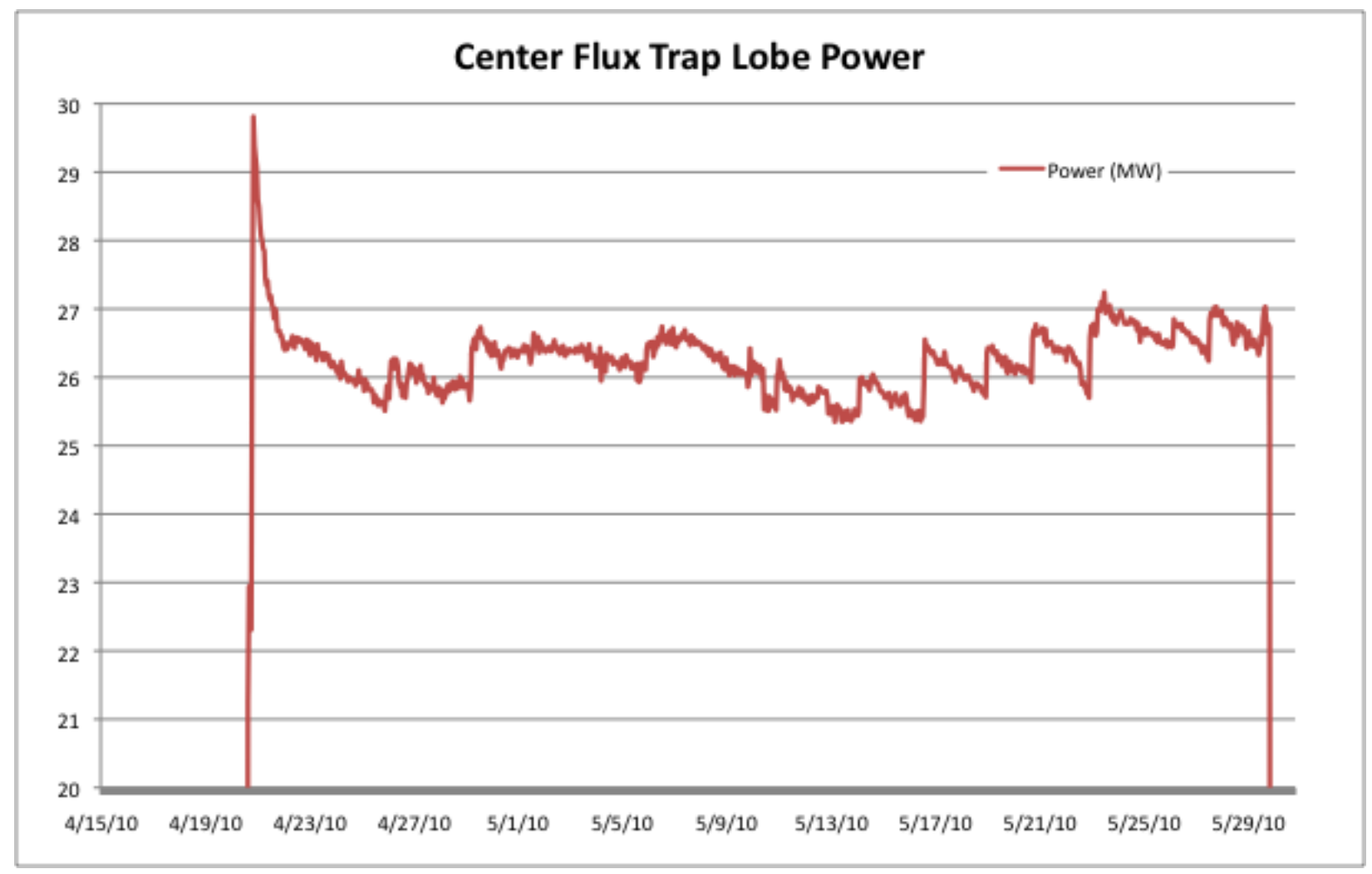

Figure 15. Center Flux Trap lobe power profile for ATR Cycle 146B. 


\subsection{Experiment Design}

The two AFIP fuel plate assemblies are configured into the experiment with coolant channels as shown in Figure 16. These coolant channels were designed to be wider than is typical in research reactor applications in order to mitigate the impact of unanticipated fuel plate pillowing or buckling and to protect the fuel plates during interim handling in the ATR canal. However, a flow restriction was incorporated to the AFIP test train to minimize coolant flow and thereby maintain the excess pressure and flow margins for the ATR primary pumps. The coolant channel hydraulic properties were measured experimentally ${ }^{15}$ and an orifice was designed based on the results. ${ }^{16}$ The orifice diameter was selected to deliver representative coolant temperature conditions in the fuel plate channels. However, new analysis described in this section has highlighted that while the orifice allows for prototypic coolant temperatures, the reduced coolant velocity also reduces the convective heat transfer coefficient between the fuel plate and coolant. This reduction in heat transfer results in a relative increase in fuel plate surface temperature for a given bulk coolant temperature.

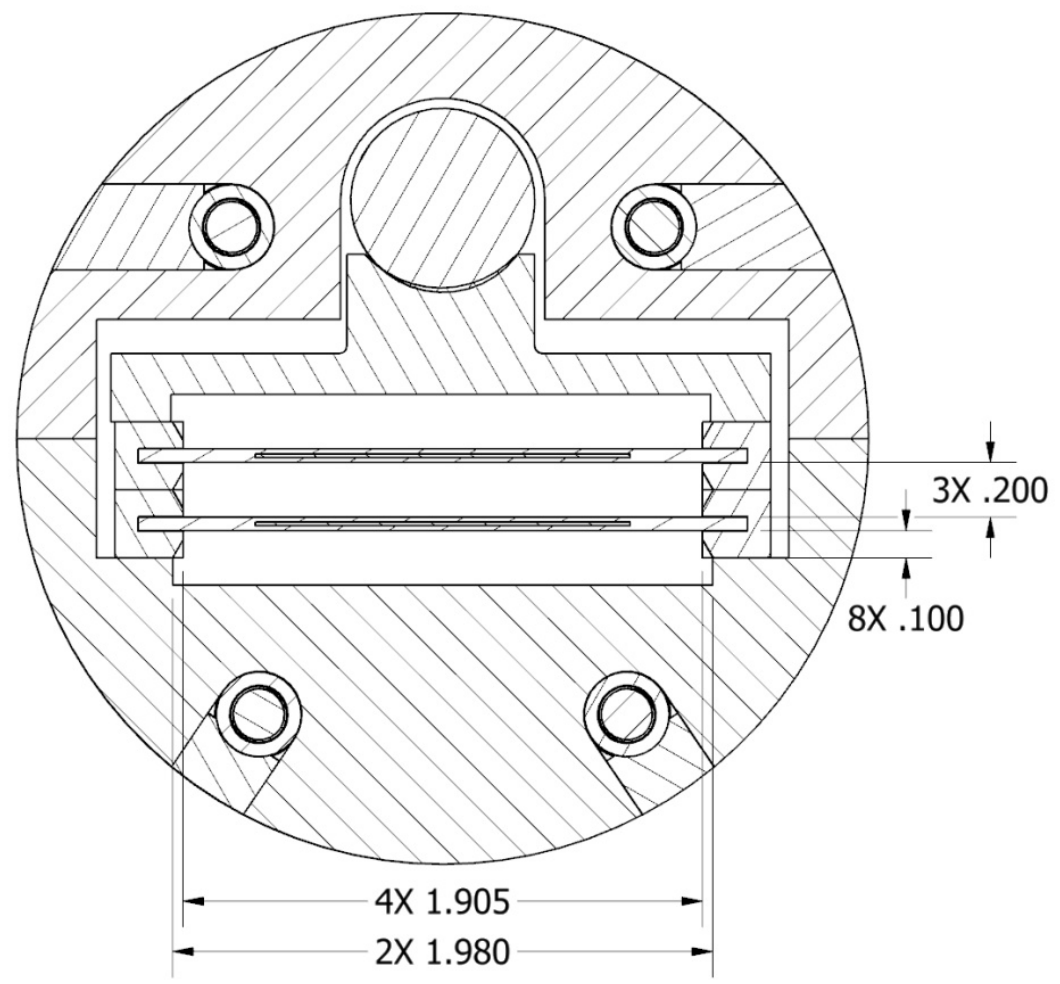

Figure 16. AFIP hardware flow channel dimensions.

The heat transfer coefficient for a given coolant flow condition and channel geometry can calculated using the Dittus-Boelter correlation.

$$
N u=\frac{h d_{h y d}}{k}=0.023 \operatorname{Pr}^{0.4} \operatorname{Re}^{0.8}
$$

where $\mathrm{Nu}$ is the Nusselt Number, $h$ is the convective heat transfer coefficient, $d_{h y d}$ is the hydraulic diameter of the channel, $k$ is the thermal conductivity of the coolant, Pr is the Prandlt Number and Re is the Reynolds Number. The heat transfer coefficient is shown as a function of coolant channel velocity for the AFIP, RERTR mini-plate, ${ }^{17}$ and Gas Test Loop mini-plate assemblies ${ }^{18}$ in Figure 17. The ATR driver element conditions ${ }^{19}$ are included for reference as well. The fuel plate surface temperatures is calculated 
from using Newton's law for convection $\left(q^{\prime \prime}=h \Delta T\right)$ and is shown for the as-designed RERTR, GTL, AFIP and ATR driver element configurations as a function of the local surface heat flux in Figure 18. This chart clearly shows a fundamental difference in the fuel plate surface temperatures experienced by a fuel plate in the AFIP configuration as opposed to a fuel plate in the other experiments under similar power conditions. For example, a RERTR mini-plate operating with a surface heat flux of $500 \mathrm{~W} / \mathrm{cm}^{2}$ would have a surface temperature roughly $75^{\circ} \mathrm{C}$ higher than the bulk coolant temperature while the surface of an AFIP plate under the same conditions would be $110^{\circ} \mathrm{C}$ above the bulk coolant temperature. This difference of $35^{\circ} \mathrm{C}$ may significantly impact the corrosion behavior in a high power test.

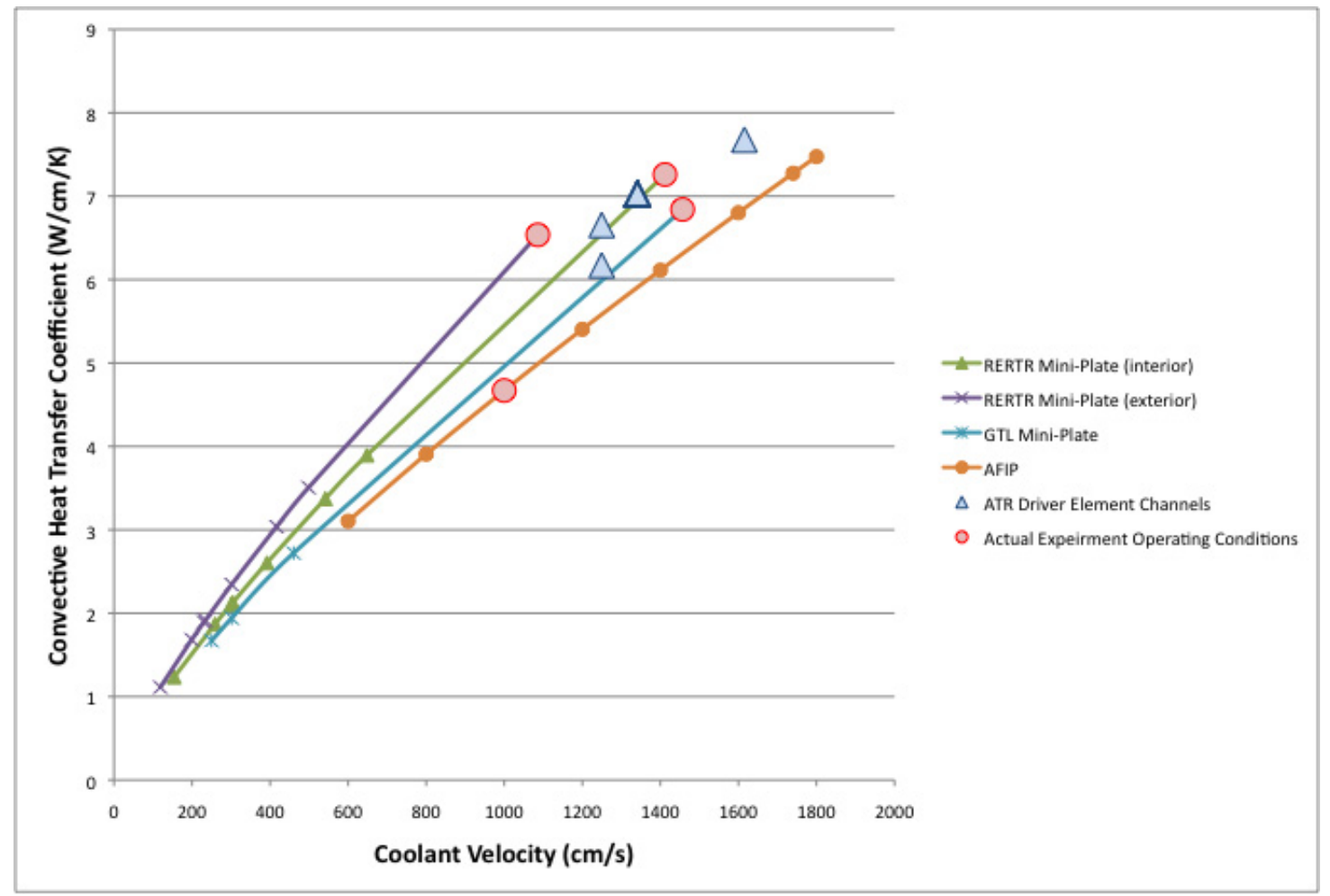

Figure 17. Convective heat transfer coefficients as a function of coolant velocity for several experiment hardware designs (RERTR, GTL, and AFIP) and the ATR driver element. 


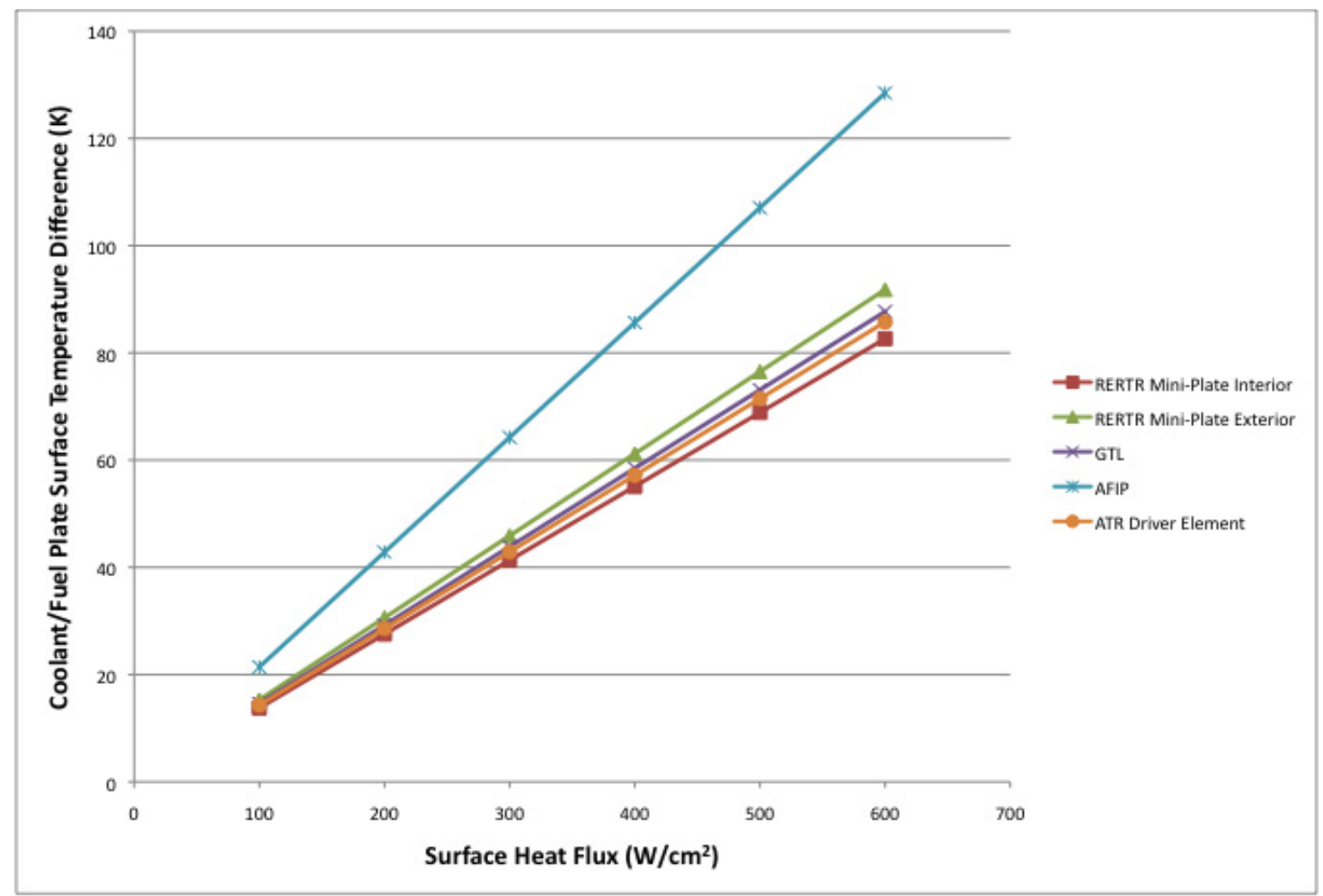

Figure 18. Coolant to Fuel Plate Surface Temperature Difference as a function of surface heat flux for the RERTR, GTL, AFIP and ATR driver element configurations.

When coupled with the calculated plate power conditions and oxide thickness measurements, the AFIP-6 fuel plate thermal conditions can readily be calculated. The axial fission density (related to power distribution) for the AFIP-6A fuel plate is shown in Figure 19. The axial peaking at the leading and exiting ends and reactor core centerline are clearly evident. The end peaking is caused by extra neutron thermalization in the neighboring non-fueled region of the plates before and after the fuel zone.

It is significant to note that the fuel meat temperature profile is very sensitive to the thermal conductivity of the oxide layer. The oxide layer consists of several layers of various material combinations and configurations. The relatively thin layer of standard boehmite on the surface has a thermal conductivity value of $0.0225 \mathrm{~W} / \mathrm{cm} / \mathrm{K}$ but beneath this layer is a relatively thick, complex layer aluminum oxide, aluminum, and porosity. The thermal conductivity of this material is not known but can be reasonably approximated by treating it as a two phase system where the remaining aluminum is dispersed in an oxide matrix. ${ }^{8}$ The effective thermal conductivity can therefore be estimated using a modified Hashin and Shtrikman correlation ${ }^{20}$

$$
K_{\text {comp }}=\frac{-K_{f}+3 V_{f} K_{f}+2 K_{m}-3 V_{f} K_{m}}{4}+\frac{\sqrt{8 K_{f} K_{m}+\left(K_{f}-3 V_{f} K_{f}-2 K_{m}+3 V_{f} K_{m}\right)^{2}}}{4}
$$

where $K_{\text {comp }}$ is the thermal conductivity of the composite material, $K_{f}$ is the conductivity of the dispersed phase (in this case aluminum), and $K_{m}$ is the matrix phase (in this case the oxide). The thermal conductivity can then be corrected to account for porosity ${ }^{21}$ using

$$
K_{P}=K_{100} e^{-2.14 P}
$$

where $k_{P}$ is the thermal conductivity of the porous materials, $k_{100}$ is the thermal conductivity of the fully-dense material, and $P$ is porosity. 
The volume fractions for the aluminum, oxide, and porosity can be estimated through examination of the micrographs shown previously in Figure 11 and microchemical analysis performed on similar layers at BR2. If the aluminum to oxide ratio is generously estimated to be $25 \%$ to $75 \%$ and the porosity is estimated at $40 \%$, the effective thermal conductivity of the composite material is on the order of 3.5 $\mathrm{W} / \mathrm{m} / \mathrm{K}$ (assuming the thermal conductivity of Al-6061 is $160 \mathrm{~W} / \mathrm{m} / \mathrm{K}$ ).

The thermal analysis results shown in Figure 20 account for variations that occur in the axial direction (including coolant temperature and fuel plate power generation) in order to predict the axially dependent temperature of the cladding and fuel meat. Two sets of curves are shown to demonstrate the affect the oxide layer has on the fuel meat temperature. One set shows the predicted temperature field based on the measured oxide thickness and the other shows the fuel meat temperature with a more typical $20 \mu \mathrm{m}$ thick oxide layer. It is clear from the plot that the most significant (by a vast margin) temperature jump occurs across the oxide layer. Assuming a normal oxide layer of less than $10 \mu \mathrm{m}$ covers the entire plate, the fuel meat centerline temperature would have remained well under $225^{\circ} \mathrm{C}$.

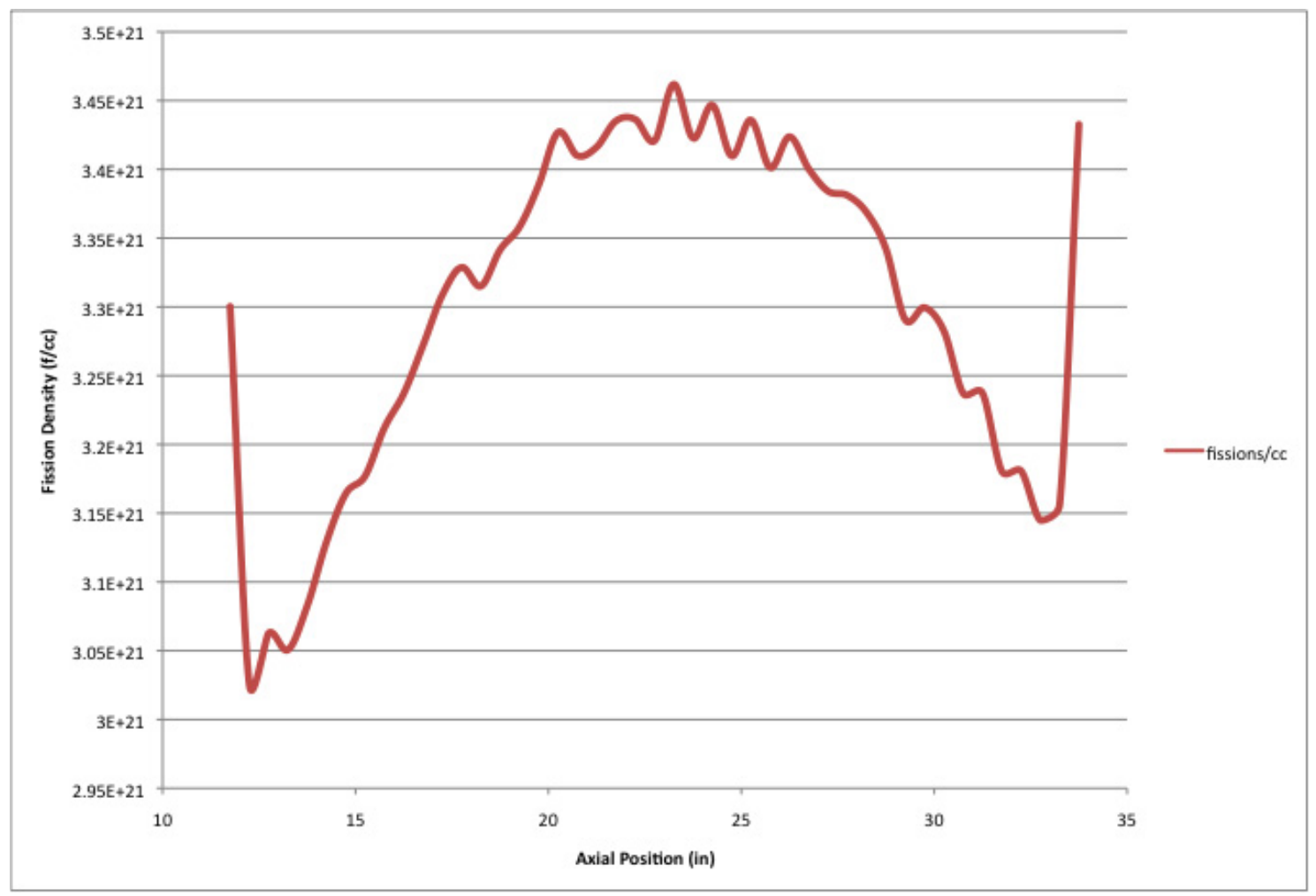

Figure 19. Calculated fission density in AFIP-6A fuel plate at the end of irradiation. 


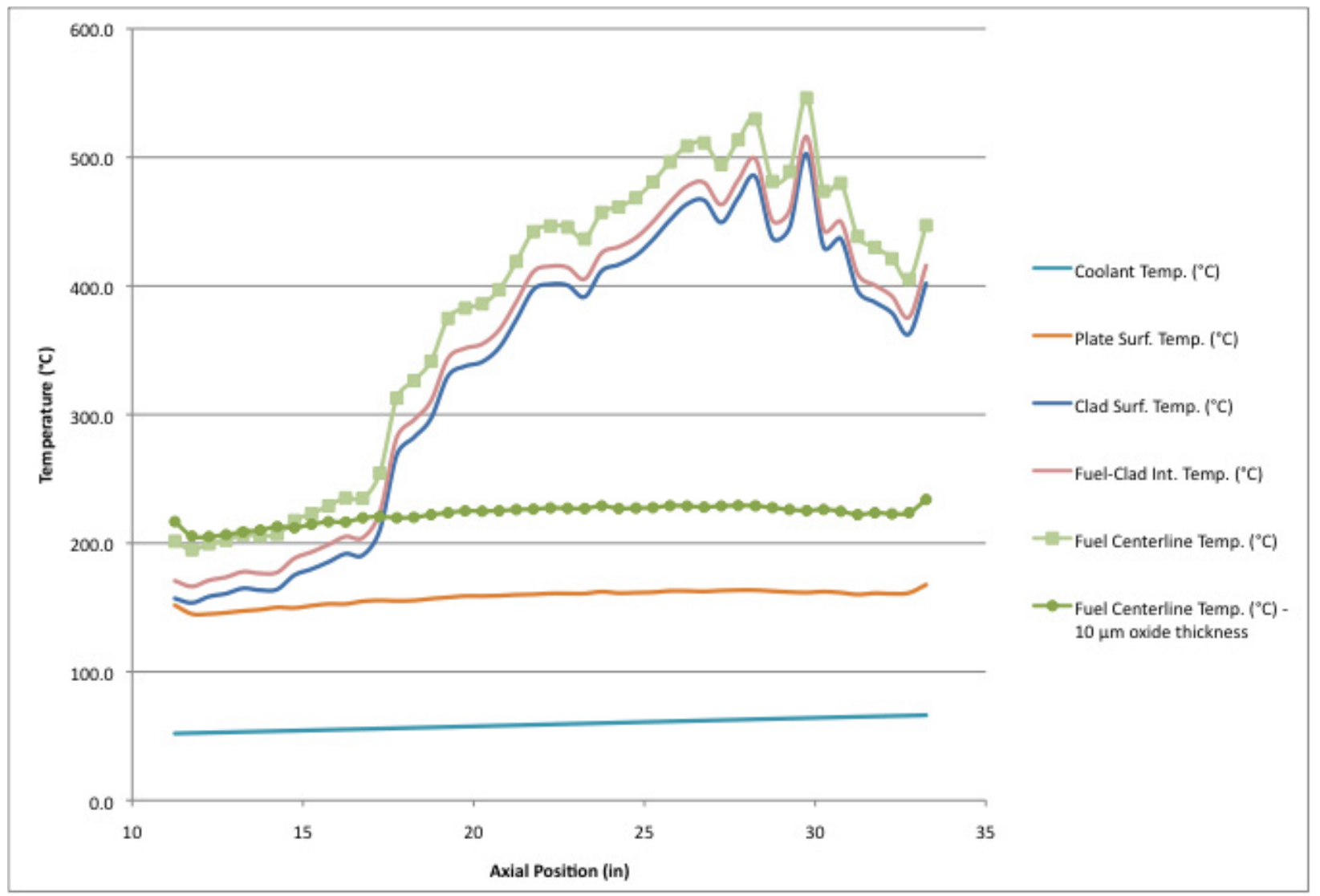

Figure 20. Estimated AFIP-6 fuel plate operating temperatures as a function of axial position on the fuel plate.

As shown in Figure 20, as the oxide layer grows its extremely low thermal conductivity significantly impacts the fuel meat operating temperature. Post irradiation annealing studies have shown that common plate type fuels (including the monolithic fuel design) become sensitive to blistering when exposed to elevated temperatures and that the threshold drops as the fission density increases. A plot of the blister threshold data for representative plate type fuels is shown in Figure $21 .^{22}$ At the end of irradiation the AFIP-6 fuel plates were estimated to reach fission densities greater than $3 \times 10^{21} \mathrm{f} / \mathrm{cc}$ with peaks as high as $\sim 3.5 \times 10^{21} \mathrm{f} / \mathrm{cc}$. At this fission density blistering could be anticipated to occur in regions of the fuel plate operating at temperatures as low as $\sim 400^{\circ} \mathrm{C}$. As the temperature profiles shown in Figure 20 indicated that significant segments of the plate are operating above this threshold, blistering is considered possible and would be first expected to occur at peak fission density locations (i.e. near the end of the fuel plate and just below the fuel plate mid-plane along the plate edges).

It is therefore apparent that the fission product releases observed during irradiation were likely caused by thermally induced blisters. These blisters were observed to form in the peak power regions of the plates (e.g. along the edges of the fuel at core centerline and at the plates lower end) where the temperature and fission density would be at a maximum. The morphology of the pores observed during metallography also support this failure mechanism. 


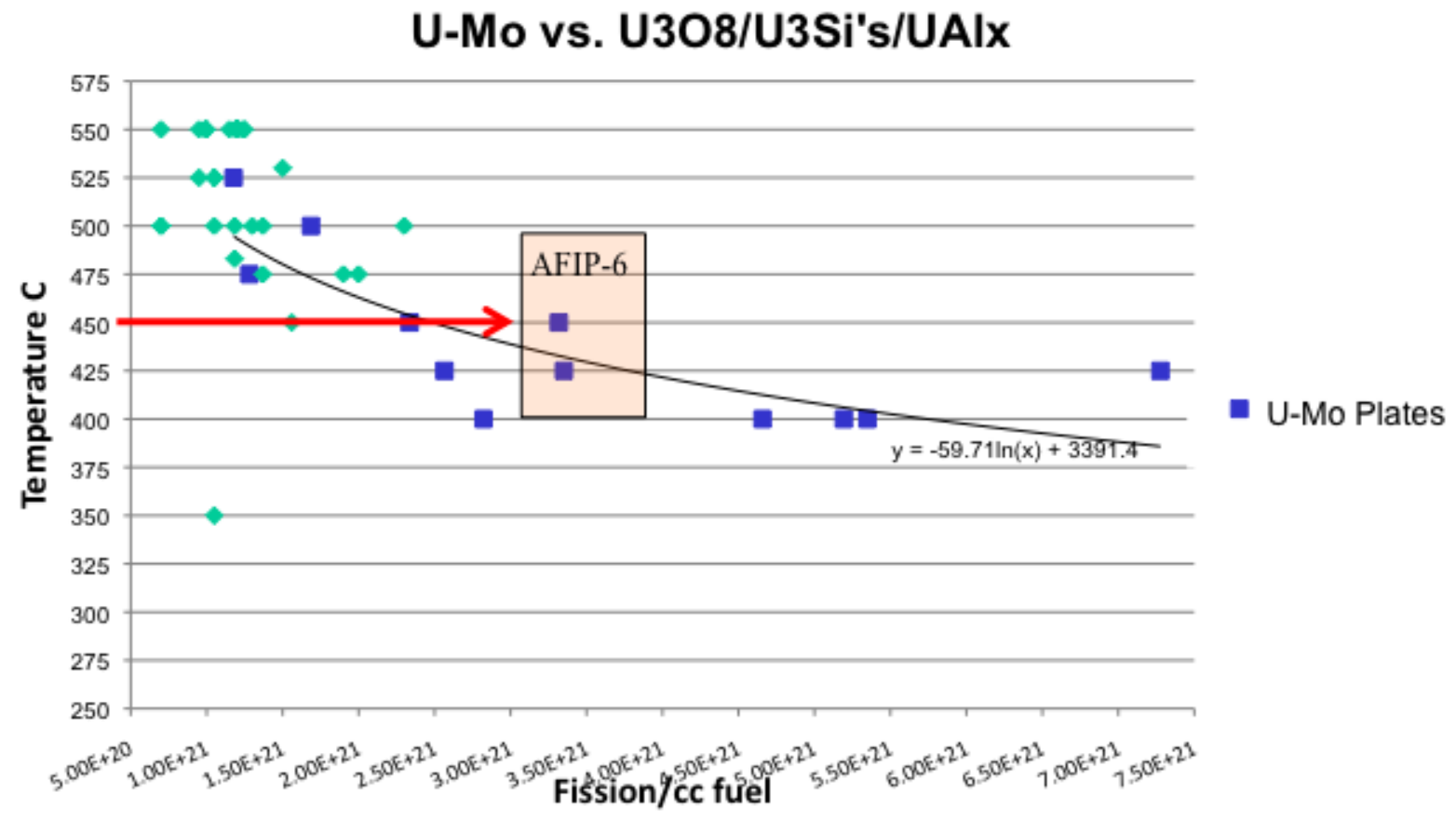

Figure 21. Blister thresholds for common aluminum clad plate type fuel. 


\section{CORROSION MODELING}

A variety of models have been developed over the last several decades to predict aluminum cladding corrosion rates during irradiation. All of these models indicate a very strong dependence on the coolant $\mathrm{pH}$ and the fuel plate surface temperature (many also indicated a secondary dependence on the surface heat flux and coolant velocity). Literature searches also revealed the following information relevant to managing corrosion in aluminum clad reactor fuels. Direct quotation of original sources is included below for clarity.

IAEA's Good Practices for Qualification of High Density Low Enriched Uranium Research Reactor Fuels (NF-T-5.2) ${ }^{23}$ state that the "fuel developer should design irradiation tests with respect to the anticipated temperature drop across the corrosion layer." "When the corrosion layer reaches a thickness that results in a given temperature drop across it, the layer tends to spall, exposing a new cladding surface to corrosion. If spalling happens enough times at a given place, the cladding may be completely consumed."

ORNL-TM- $11517^{24}$ suggests that "avoiding spallation sets a more stringent requirement than does the fuel temperature limit."

Yoder et al. ${ }^{25}$ reports that "spallation is often accompanied by structural damage of the aluminum in the form of blisters or subsurface reaction products and voids within the aluminum matrix. Spallation may also be caused by other stresses induced during the oxidation process itself or by imposed thermal gradients."

ORNL- $6574^{26}$ provides important metallographic results obtained by examination of corrosionaffected aluminum cladding: "Metallographic inspection of cross sections of such specimens revealed severe attack within the metal underlying the spalled film. The depth of the reaction zone, which seemed to be composed of oxide material and perhaps voids (or bubbles) located on grain boundaries and within the metal grains, in several instances exceeded $0.2 \mathrm{~mm} . "$

Based on these phenomenological descriptions, the spallation-induced fuel plate failure mechanism is likely to proceed as follows:

- Corrosion buildup due to elevated oxide-water surface temperature and prolonged irradiation time.

- Oxide spallation occurs when temperature difference across the oxide layer reaches $119^{\circ} \mathrm{C}$ (driven by the oxide thickness and the local surface heat flux).

- Loss of corrosion protection normally provided by the boehmite film.

- Development of the reaction zone (Figure 22) in cladding regions affected by the spallation. The reaction zone is composed of the oxide and voids (up to 200 microns thick).

- Plate blistering in the affected regions due to impairment of heat removal. Impairment of heat removal is due to formation of the reaction zone composed of the oxide and voids.

- Cladding breach and release of fission products into the coolant. 


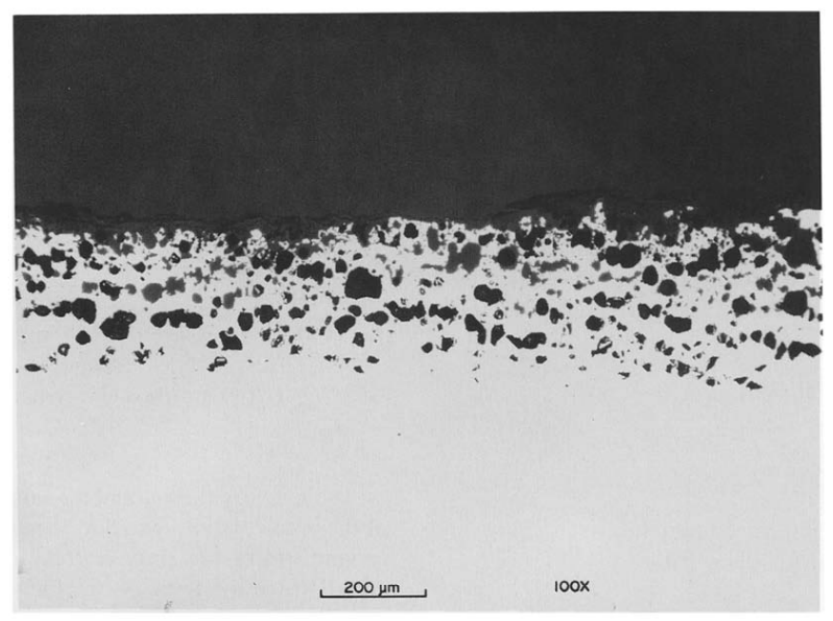

Figure 22. Specimen cross-section after spallation with subsurface attack. ${ }^{25}$

To avoid spallation, Yoder et al. ${ }^{25}$ proposed a specific thermal limit for Al-clad research reactor fuel based on experiment results. This limit states that temperature difference across the oxide layer must not exceed $119^{\circ} \mathrm{C}$.

Based on the one-dimensional heat transfer law perpendicular to the plate surface, the temperature difference across the oxide layer is a function of the heat flux, the oxide thermal conductivity, and the oxide thickness:

$$
\Delta T_{o x}=\frac{q^{\prime \prime} t_{o x}}{k_{o x}}
$$

where $\mathrm{q}$ " is the heat flux in $\mathrm{W} / \mathrm{cm}^{2}, \mathrm{t}_{\mathrm{ox}}$ oxide thickness in centimeters, $\mathrm{k}_{\mathrm{ox}}$ is the oxide thermal conductivity in $\mathrm{W} / \mathrm{cm}-\mathrm{K}$.

Evolution of the oxide thickness with time is described using the equation known as ATR-corrected Griess correlation: ${ }^{27}$

$t_{o x}=0.7 \cdot 25.4 \cdot 443 \cdot \theta^{0.778} \cdot \exp (-4600 / T)$

where $\mathrm{t}_{\mathrm{ox}}$ is oxide thickness in microns, $\theta$ is time in hours and $\mathrm{T}$ is the oxide-water surface temperature in degrees Kelvin.

Substituting equation (2) into equation (1) yields the following:

$$
\Delta T_{o x}=0.787654 \cdot \frac{q^{\prime \prime}}{k_{o x}} \cdot \theta^{0.778} \cdot \exp (-4600 / T)
$$

Substituting Yoder's spallation criterion $\Delta T_{o x}=119 \mathrm{~K}$, and $\mathrm{k}_{\mathrm{ox}}=0.0225 \mathrm{~W} / \mathrm{cm}-\mathrm{K},{ }^{28}$ equation (3) can be rearranged to calculate irradiation time in days to spallation onset:

$\theta=\frac{1}{24}\left(\frac{3.4}{q^{\prime \prime} \cdot \exp (-4600 / T)}\right)^{1.285}$

Equation (4) is plotted in Figure 23 for the given heat flux values $200-600 \mathrm{~W} / \mathrm{cm}^{2}$. 


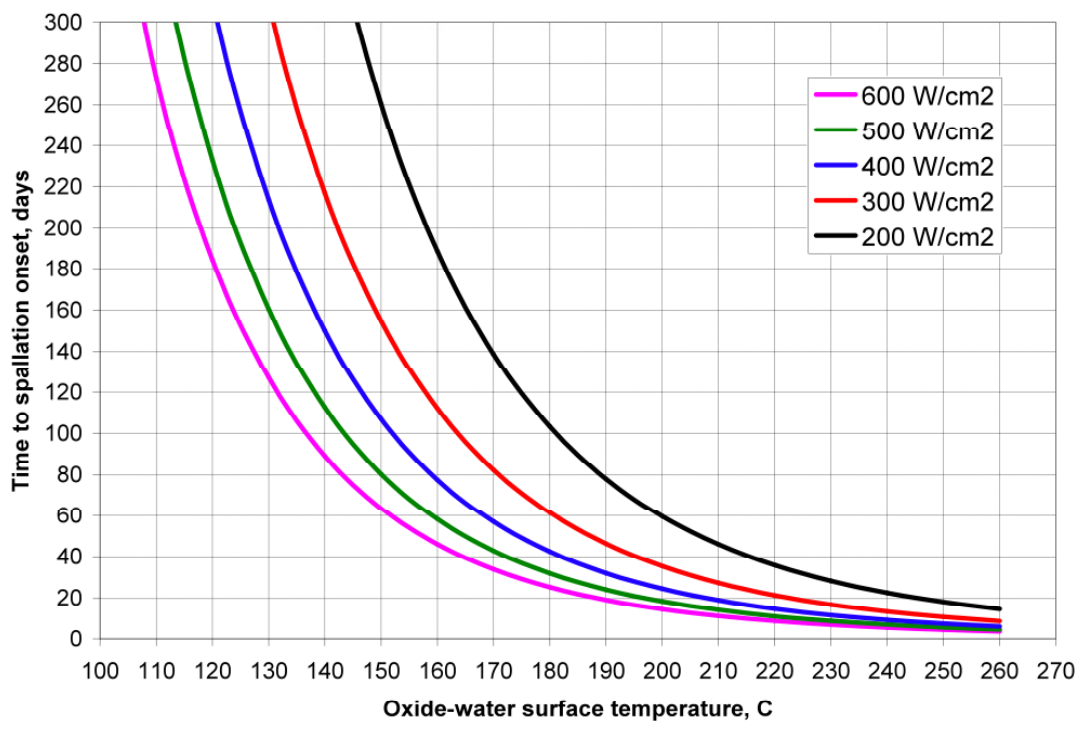

Figure 23. Irradiation time to the spallation onset for a range of the heat flux values. Given expected heat flux and oxide-water surface temperature, the chart can be used to estimate irradiation time to the onset of spallation.

It is recommended that Equation (2) and Equation (3) be used during experiment design to verify that that spallation will not occur. It is important to apply this criterion to the local conditions (heat flux and oxide-water surface temperature).

In order to predict the onset of spallation, growth of the normal boehmite layer must first be accurately predicted for the operating conditions of the specific fuel plates to be tested. The ATR-corrected Griess correlation was developed based on irradiation experiments conducted with an instrumented fuel plate in the $\mathrm{ATR}^{27}$ (correction was required since the original Griess correlation is based on out-of-pile experiments ${ }^{28}$ ). To demonstrate applicability of the ATR-corrected Griess correlation to the RERTR experiments, the correlation was used to calculate the oxide thickness for the GTL-1, RERTR-10A, and AFIP-6 experiments and the calculation results were compared with the measured data. The plot comparing calculated and measured data is shown in Figure 25.

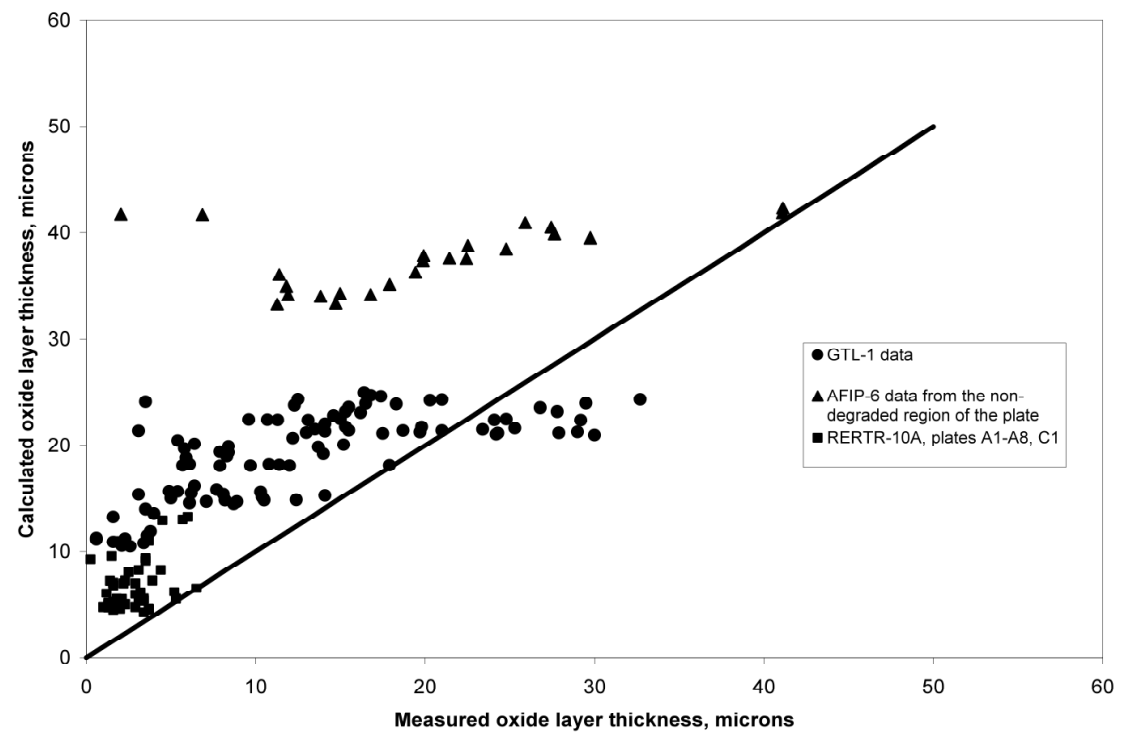

Figure 24. Oxide thickness calculated using Equation (2) versus measured oxide thickness. 
As evident from Figure 24, Equation (2) provides a conservative assessment of the oxide thickness in most of the cases. Based on this result, it is established that the ATR-corrected Griess correlation is applicable to predicting pre-spallation oxide growth on aluminum clad experimental plates.

\section{Interpretation of the AFIP-6 results}

The methodology to predict oxide spallation described in the ECAR- $1374^{29}$ was applied to the AFIP-6 experiment. In the calculation described below, the heat flux values reported in ECAR-1366 ${ }^{12}$ were multiplied by a factor of 1.13 based on the examination of the as-built fuel plate thickness data ${ }^{6}$ which showed that uranium loading in the plate, while within specifications, exceeded the nominal values by $13 \%$ on average. Since ECAR- $1366^{12}$ was developed based on nominal uranium loadings, the $13 \%$ scaling factor was applied to the as-run power history accordingly.

The analysis projected that spallation would occur at the bottom node of the plate on the $29^{\text {th }}$ day of irradiation. Table 3 shows oxide thickness, temperature drop across the oxide layer and an indication whether spallation has occurred for the axial locations on the plate predicted for the $29^{\text {th }}$ day of irradiation. Table 4 shows indication whether spallation has occurred for the axial locations on the plate at the end of irradiation (39.3 days).

The data represented in both of these Tables is in agreement with observations made for the AFIP-6 experiment where the first cladding breach was identified after 31 days of irradiation ( 2 days after the predicted onset of spallation) and that the fuel plate would be roughly $2 / 3$ covered with spalled oxide after 39 days of irradiation (which is consistent with post irradiation examination results).

\section{Evaluation of the planned AFIP-7 experiment}

AFIP-7 thermal evaluation ${ }^{30}$ projects a bounding maximum heat flux of $382 \mathrm{~W} / \mathrm{cm}^{2}$ and maximum cladding surface temperature of $129^{\circ} \mathrm{C}$ during peak power operating conditions. Substituting these values into equation described in ECAR-1374:

$$
\theta=\frac{1}{24}\left(\frac{3.4}{q^{\prime \prime} \cdot \exp (-4600 / T)}\right)^{1.285},
$$

it is determined that oxide spallation will occur on the $234^{\text {th }}$ day of irradiation. As the experiment is only planned for two irradiation cycles (and thus $\sim 100$ days irradiation) it is extremely unlikely to be susceptible to spallation type corrosion. 
Table 3. Oxide thickness, temperature drop across the oxide layer and indication whether spallation has occurred for the axial locations on the plate predicted for the 29th day of AFIP-6 irradiation.

\begin{tabular}{|c|c|c|c|c|}
\hline $\begin{array}{l}\text { Axial node } \\
\text { number }\end{array}$ & $\begin{array}{l}\text { Dist. from } \\
\text { the meat } \\
\text { top, cm }\end{array}$ & $\begin{array}{l}\text { Oxide } \\
\text { thickn., } \\
\text { micron }\end{array}$ & $\begin{array}{l}\text { Temparature } \\
\text { drop across } \\
\text { the oxide layer, } \\
\text { C }\end{array}$ & $\begin{array}{l}\text { Spallation } \\
\text { occurred? }\end{array}$ \\
\hline 1 & 1.27 & 42.20 & 97 & NO \\
\hline 2 & 2.54 & 32.91 & 69 & NO \\
\hline 3 & 3.81 & 34.35 & 72 & NO \\
\hline 4 & 5.08 & 33.95 & 72 & NO \\
\hline 5 & 6.35 & 34.78 & 74 & NO \\
\hline 6 & 7.62 & 36.18 & 78 & NO \\
\hline 7 & 8.89 & 37.56 & 82 & NO \\
\hline 8 & 10.16 & 38.06 & 84 & NO \\
\hline 9 & 11.43 & 38.77 & 86 & NO \\
\hline 10 & 12.70 & 39.81 & 89 & NO \\
\hline 11 & 13.97 & 41.45 & 93 & NO \\
\hline 12 & 15.24 & 42.65 & 97 & NO \\
\hline 13 & 16.51 & 43.34 & 98 & NO \\
\hline 14 & 17.78 & 43.01 & 99 & NO \\
\hline 15 & 19.05 & 43.96 & 102 & NO \\
\hline 16 & 20.32 & 44.85 & 103 & NO \\
\hline 17 & 21.59 & 45.37 & 105 & NO \\
\hline 18 & 22.86 & 47.58 & 112 & NO \\
\hline 19 & 24.13 & 46.84 & 110 & NO \\
\hline 20 & 25.40 & 46.96 & 110 & NO \\
\hline 21 & 26.67 & 47.90 & 112 & NO \\
\hline 22 & 27.94 & 48.19 & 113 & NO \\
\hline 23 & 29.21 & 47.18 & 111 & NO \\
\hline 24 & 30.48 & 49.31 & 115 & NO \\
\hline 25 & 31.75 & 47.72 & 111 & $\mathrm{NO}$ \\
\hline 26 & 33.02 & 48.31 & 112 & NO \\
\hline 27 & 34.29 & 47.37 & 111 & NO \\
\hline 28 & 35.56 & 48.58 & 113 & NO \\
\hline 29 & 36.83 & 46.95 & 109 & NO \\
\hline 30 & 38.10 & 48.09 & 112 & NO \\
\hline 31 & 39.37 & 46.97 & 109 & NO \\
\hline 32 & 40.64 & 46.52 & 108 & NO \\
\hline 33 & 41.91 & 46.66 & 109 & NO \\
\hline 34 & 43.18 & 46.36 & 107 & NO \\
\hline 35 & 44.45 & 45.34 & 104 & $\mathrm{NO}$ \\
\hline 36 & 45.72 & 43.58 & 99 & NO \\
\hline 37 & 46.99 & 43.85 & 100 & NO \\
\hline 38 & 48.26 & 43.84 & 98 & NO \\
\hline 39 & 49.53 & 41.91 & 94 & NO \\
\hline 40 & 50.80 & 42.34 & 94 & NO \\
\hline 41 & 52.07 & 40.70 & 90 & NO \\
\hline 42 & 53.34 & 40.36 & 88 & NO \\
\hline 43 & 54.61 & 39.63 & 87 & NO \\
\hline 44 & 55.88 & 40.00 & 87 & $\mathrm{NO}$ \\
\hline 45 & 57.15 & 49.94 & 119 & YES \\
\hline
\end{tabular}

Table 4. Temperature drop across the oxide layer and indication whether spallation has occurred for the axial locations on the plate predicted for the end of AFIP-6 irradiation.

\begin{tabular}{|c|c|c|}
\hline $\begin{array}{l}\text { Axial node } \\
\text { number }\end{array}$ & $\begin{array}{l}\text { Spallation } \\
\text { occurred? }\end{array}$ & $\begin{array}{l}\text { Temparature } \\
\text { drop across } \\
\text { the oxide } \\
\text { layer, C }\end{array}$ \\
\hline 1 & YES & 142 \\
\hline 2 & $\mathrm{NO}$ & 101 \\
\hline 3 & NO & 104 \\
\hline 4 & NO & 104 \\
\hline 5 & NO & 108 \\
\hline 6 & NO & 113 \\
\hline 7 & YES & 120 \\
\hline 8 & YES & 121 \\
\hline 9 & YES & 125 \\
\hline 10 & YES & 130 \\
\hline 11 & YES & 133 \\
\hline 12 & YES & 140 \\
\hline 13 & YES & 140 \\
\hline 14 & YES & 141 \\
\hline 15 & YES & 144 \\
\hline 16 & YES & 147 \\
\hline 17 & YES & 151 \\
\hline 18 & YES & 157 \\
\hline 19 & YES & 154 \\
\hline 20 & YES & 154 \\
\hline 21 & YES & 157 \\
\hline 22 & YES & 158 \\
\hline 23 & YES & 158 \\
\hline 24 & YES & 159 \\
\hline 25 & YES & 156 \\
\hline 26 & YES & 158 \\
\hline 27 & YES & 156 \\
\hline 28 & YES & 157 \\
\hline 29 & YES & 154 \\
\hline 30 & YES & 157 \\
\hline 31 & YES & 154 \\
\hline 32 & YES & 152 \\
\hline 33 & YES & 154 \\
\hline 34 & YES & 152 \\
\hline 35 & YES & 149 \\
\hline 36 & YES & 143 \\
\hline 37 & YES & 142 \\
\hline 38 & YES & 139 \\
\hline 39 & YES & 135 \\
\hline 40 & YES & 134 \\
\hline 41 & YES & 129 \\
\hline 42 & YES & 127 \\
\hline 43 & YES & 126 \\
\hline 44 & YES & 126 \\
\hline 45 & YES & 169 \\
\hline
\end{tabular}




\section{CONCLUSIONS AND RECOMMENDATIONS}

The AFIP-6 experiment breach can be summarized as follows:

- The breach occurred due to the formation of small surface blisters in the peak temperature regions of the fuel plates.

- The overall fuel plate operating thermal conditions were well outside the intended conditions due to severe oxidation of the aluminum cladding.

- Severe oxidation of the cladding occurred due to higher than intended fuel plate operating temperatures as a result of low convective heat transfer coefficient in the coolant channel. The high surface temperature accelerated oxide growth until the spallation threshold was reached leading to significant degradation of the cladding surface.

- The convective heat transfer coefficient was lower than necessary due to the increased size of the coolant channels and a test train flow restriction added to minimize coolant flow through the CFT.

Future testing of aluminum clad fuel plates at high power will require a detailed review of projected operating surface temperatures and the database describing corrosion behavior under those conditions. An operating limit will need to be established for each experiment specific to its operating conditions (surface temperature and residence time) that will provide a reasonable margin to breakaway oxidation and fuel meat blistering like that seen in the AFIP-6 experiment. A methodology to perform this assessment is outlined in the report. This requirement will be incorporated into the experiment design reviews for all future aluminum clad experiments. 


\section{REFERENCES}

1. D. M. Wachs, "RERTR Fuel Development and Qualification Plan,” INL/EXT-10-05017, April 2010.

2. D. M. Wachs, "Experiment Control Plan for the AFIP-6 Irradiation in the ATR," PLN-3222.

3. G. S. Chang, "ATR LEU Monolithic and Dispersed with 10B Loading Minimization Design Neutronics Performance Analysis," INL/CON-10-19405.

4. G. A. Moore, "Fabrication Control Plan for the AFIP-6 Experiment," PLN-3441.

5. N. E. Woolstenhulme, "Specification for AFIP Fuel Plates and Assemblies for Irradiation in the ATR,” TFR-662, INL/MIS-10-18037.

6. G. A. Moore. "AFIP-6 As-Built Data Package."

7. C. Jensen, "Chronology of the Cycle 146B AFIP Experiment Leak (and) History of ATR Leaking Fuel,” INL/INT-10-20638.

8. A. Leenaers, et. al., "Microstructure of $\mathrm{U}_{3} \mathrm{Si}_{2}$ Fuel Plates Submitted to a High Heat Flux," Journal of Nuclear Materials, 327 (2004) pg. 121-129.

9. D. L. Selby, R.M. Harrington, ORNL—6574 "Advanced Neutron Source Project Progress Report," April 1990.

10. R. F. Whitacre, “The UAlx Fuel Dispersion System,” EGG-PRP-8783, November 1989

11. J. M. Beeston, et al., "Development and Irradiation Performance of Uranium Aluminide Fuel in Test Reactors," Journal of Nuclear Technology, vol. 49, June 1980.

12. M. A. Lillo and G. S. Chang, "As-Run Neutronic Analysis for the AFIP-6 Experiment Irradiated in the Center Flux Trap of the ATR, Cycle 146B," ECAR-1366.

13. G.A. Moore, "Fuel Loading Calculations For The AFIP-6 Irradiation Experiment," ECAR-929.

14. G.S. Chang and M A. Lillo, "Detailed Fission Power 2D-Mapping of AFIP-2 Experiment in ATR CFT Position.” INL/CON-07-13152, May 2008.

15. D. M. Wachs, "Hydraulic Testing of the AFIP Irradiation Vehicle for the ATR Center Flux Trap," ECAR-99.

16. R. G. Ambrosek, "RELAP Analysis for the AFIP-2 Flow Restrictor," ECAR-126.

17. D. M. Wachs, “ RERTR Large B Position Irradiation Vehicle Flow Test,” EDF-8292.

18. D. M. Wachs, “GTL Mini-plate Experiment Flow Test,” EDF-7531.

19. M. L. Griebenow, "Isothermal Hydraulic Measurements in Fuel Elements in ATR Core," IN-1158, pg. 70.

20. Z. Hashin and S. Shtrikman, "A Variational Approach to the Theory of the Effective Magnetic Permeability of Multiphase Materials," Journal of Applied Physics, Vol. 33 (1962) pp. 3125-3131.

21. M. E. Cunningham and K. L. Peddicord, "Heat Conduction in Spheres Packed in an Infinite Regular Cubical Array," International Journal of Heat and Mass Transfer, Vol. 24 (1981) pp. 1081-1088.

22. F. J. Rice, "Monolithic U-Mo Plate Blister Analysis,” ECAR-1372.

23. IAEA NUCLEAR ENERGY SERIES, Report No. NF-T-5.2, Good Practices for Qualification of High Density Low Enriched Uranium Research Reactor Fuels, International 
Atomic Energy Agency Vienna, 2009, http://wwwpub.iaea.org/MTCD/publications/PDF/pub1400 web.pdf.

24. R. E. Pawel, G. L. Yoder, C. D. West, B. H. Montgomery The Development of a Preliminary Correlation of Data on Oxide Growth on 6061 Aluminum Under ANS Thermal-Hydraulic Conditions, ORNL-TM-11517, http:/www.osti.gov/bridge/servlets/purl/5780409RFWVZX/native/5780409.pdf.

25. G. L. Yoder, N.C.J. Chen, D. K. Felde, W. R. Nelson and R. E. Pawel, The effect of aluminum corrosion on the Advanced Neutron Source Reactor fuel design, Nuclear Engineering and Design 136 (1992) 401-408.

26. M. R. McBee, C. M. Chance, Advanced Neutron Source (ANS) Project progress report, ORNL-6574 http://www.osti.gov/bridge/servlets/purl/6995501-jpBkIU/.

27. M. L. Griebenow, G. H. Hanson, M. J. Graber, Jr., D. S. Fjeld, ATR Startup Fuel-Plate-Cladding Corrosion Test: Preliminary Data and Conclusions, American Nuclear Society 1971 Winter meeting transactions, October 17-21, 1971, Vol. 14, Number 2, pages 761 and 762 .

28. J. C. Greiss et al., Effect of Heat Flux on the Corrosion of Aluminum by Water Part IV, ORNL-3541, February 1964.

29. P. Medvedev, "An Approach to Managing Corrosion in During Irradiaiton of Aluminum Clad Fuels," ECAR-1374.

30. G. Roth, “AFIP-7 Thermal Evaluation,” ECAR-1629. 